Prepared in cooperation with the Wyoming Department of Environmental Quality

\title{
Water-Quality Characteristics, Including Sodium-Adsorption Ratios, for Four Sites in the Powder River Drainage Basin, Wyoming and Montana, Water Years 2001-2004
}

Scientific Investigations Report 2006-5113

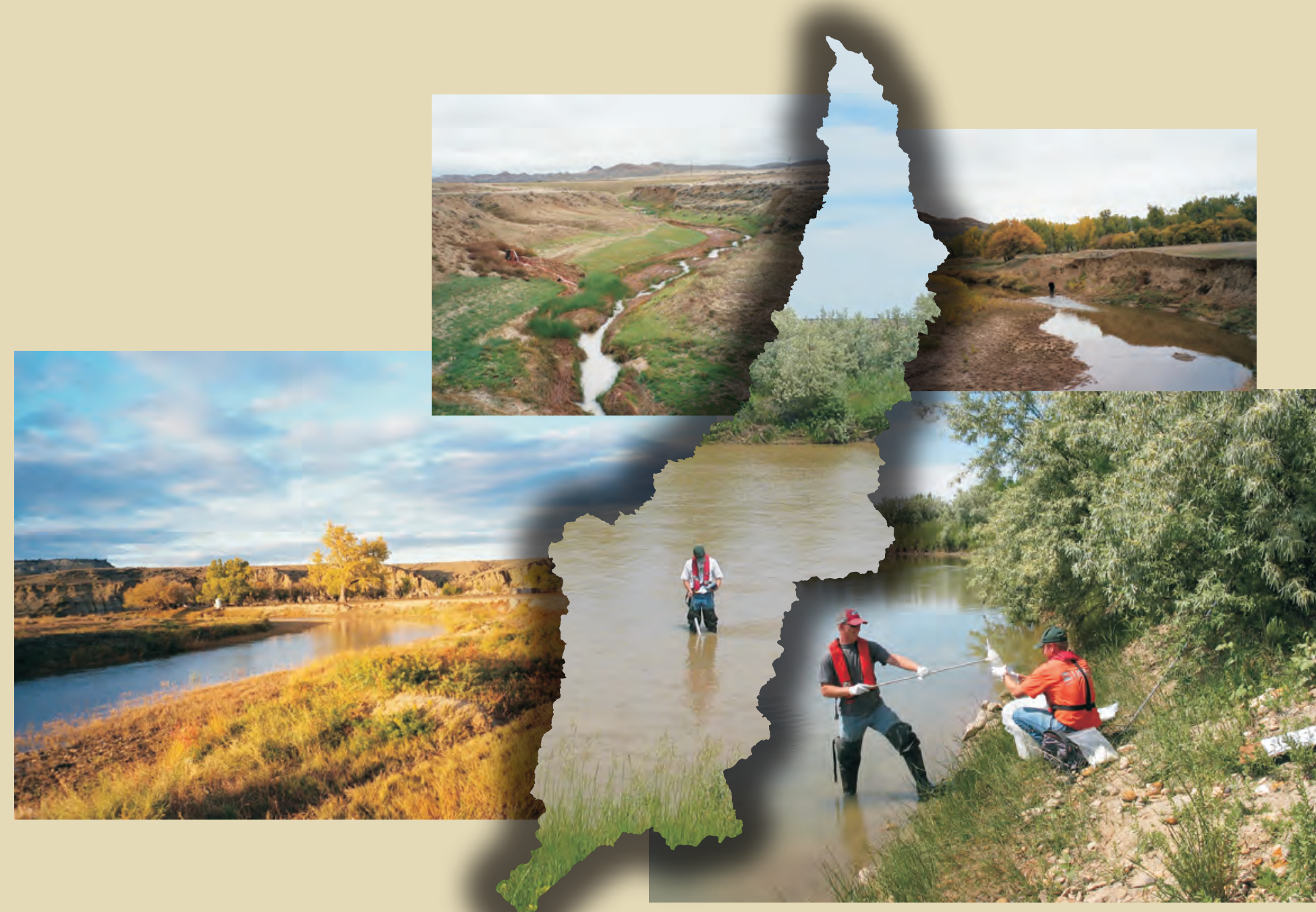




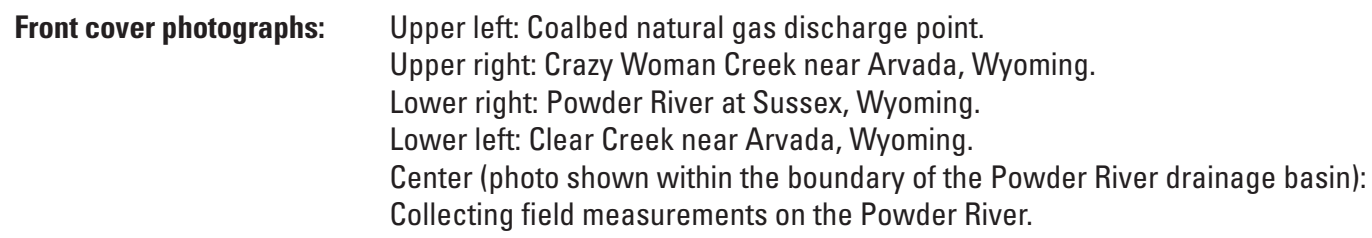

Back cover photograph: Water-quality sampling on Crazy Woman Creek, Wyoming.

All photographs by Melanie L. Clark, USGS. 


\section{Water-Quality Characteristics, Including Sodium-Adsorption Ratios, for Four Sites in the Powder River Drainage Basin, Wyoming and Montana, Water Years 2001-2004}

By Melanie L. Clark and Jon P. Mason

Prepared in cooperation with the Wyoming Department of Environmental Quality

Scientific Investigations Report 2006-5113 


\section{U.S. Department of the Interior \\ Dirk Kempthorne, Secretary \\ U.S. Geological Survey \\ P. Patrick Leahy, Acting Director}

\section{U.S. Geological Survey, Reston, Virginia: 2006}

For product and ordering information:

World Wide Web: http://www.usgs.gov/pubprod

Telephone: 1-888-ASK-USGS

For more information on the USGS--the Federal source for science about the Earth, its natural and living resources, natural hazards, and the environment:

World Wide Web: http://www.usgs.gov

Telephone: 1-888-ASK-USGS

Any use of trade, product, or firm names is for descriptive purposes only and does not imply endorsement by the U.S. Government.

Although this report is in the public domain, permission must be secured from the individual copyright owners to reproduce any copyrighted materials contained within this report.

Suggested citation:

Clark, M.L., and Mason, J.P., 2006, Water-quality characteristics, including sodium-adsorption ratios, for four sites in the Powder River drainage basin, Wyoming and Montana, water years 2001-2004: U.S. Geological Survey Scientific Investigations Report 2006-5113, 22 p. 


\section{Contents}

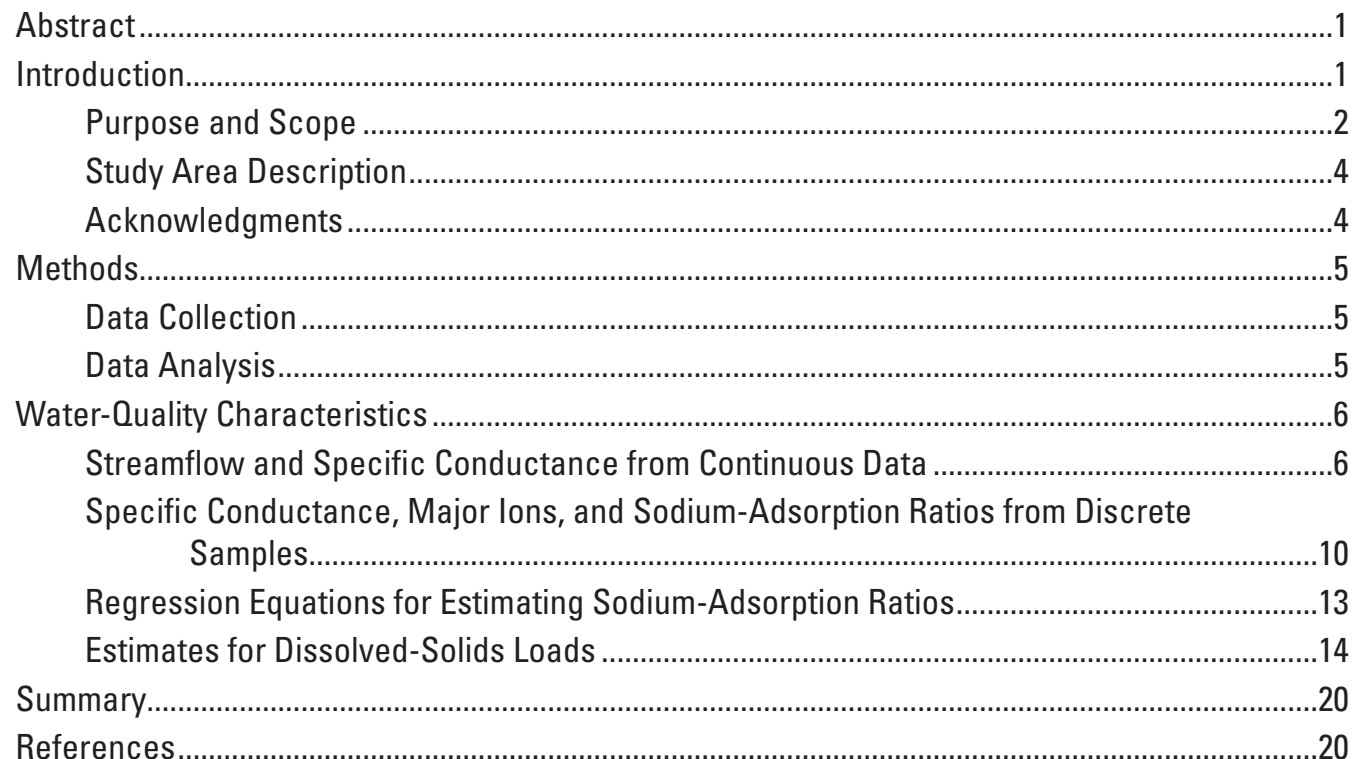

\section{Figures}

1. Map showing location of continuous water-quality sampling sites in the

Powder River drainage basin, Wyoming and Montana, water years 2001-2004.

2-4. Graphs showing:

2. Daily mean streamflow and specific conductance for sites in the Powder River drainage basin, Wyoming and Montana, water years 2001-2004. .

3. Specific conductance values; concentrations of dissolved calcium, dissolved magnesium, and dissolved sodium; sodium-adsorption ratios; and dissolvedsolids concentrations in water-quality samples collected from sites in the Powder River drainage basin, Wyoming and Montana, water years 2001-2004.

4. Dissolved-solids concentrations in relation to specific conductance in water-quality samples collected from sites in the Powder River drainage basin, Wyoming and Montana, water years 2001-2004.

5. Diagram showing specific conductance and sodium-adsorption ratio and potential for reduction in rate of infiltration for water-quality samples collected from sites in the Powder River drainage basin, Wyoming and Montana, water years 2001-2004.

6-8. Graphs showing:

6. Sodium-adsorption ratios in relation to specific conductance in water-quality samples collected from sites in the Powder River drainage basin, Wyoming and Montana, water years 2001-2004.

7. Estimated and calculated sodium-adsorption ratios for sites in the Powder River drainage basin, Wyoming and Montana, water years 2001-2004.

8. Estimated and calculated dissolved-solids loads for sites in the Powder River drainage basin, Wyoming and Montana, water years 2001-2004. 


\section{Tables}

1. Selected streamflow characteristics for water-quality monitoring sites in the Powder River drainage basin, Wyoming and Montana.

2. Period of record for discrete water-quality sample collection for sites in the Powder River drainage basin, Wyoming and Montana, water years 2001-2004. 7

3. Period of record for continuous data collection for sites in the Powder River drainage basin, Wyoming and Montana, water years 2001-2004.

4. Regression equations for estimates of sodium-adsorption ratios for sites in the Powder River drainage basin, Wyoming and Montana, water years 2001-2004.

5. Summary statistics of LOADEST regression models used to estimate daily mean dissolved-solids loads for sites in the Powder River drainage basin, Wyoming and Montana, water years 2001-2004.

6. Estimated dissolved-solids annual loads and runoff-weighted loads for sites in the Powder River drainage basin, Wyoming and Montana, water years 2001-2004. . .18

\section{Conversion Factors and Datums}

\begin{tabular}{lcl}
\hline Multiply & By & To obtain \\
\hline inch (in.) & Length & \\
inch (in.) & 2.54 & centimeter $(\mathrm{cm})$ \\
foot (ft) & 25.4 & millimeter $(\mathrm{mm})$ \\
mile (mi) & 0.3048 & meter $(\mathrm{m})$ \\
\hline & 1.609 & kilometer $(\mathrm{km})$ \\
\hline acre & Area & \\
square mile $\left(\mathrm{mi}^{2}\right)$ & 4,047 & square meter $\left(\mathrm{m}^{2}\right)$ \\
\hline cubic foot $\left(\mathrm{ft}{ }^{3}\right)$ & 2.590 & square kilometer $\left(\mathrm{km}^{2}\right)$ \\
acre-foot $(\mathrm{acre}-\mathrm{ft})$ & Volume & cubic meter $\left(\mathrm{m}^{3}\right)$ \\
acre-foot $(\mathrm{acre}-\mathrm{ft})$ & 0.02832 & cubic meter $\left(\mathrm{m}^{3}\right)$ \\
\hline & 1,233 & cubic hectometer $\left(\mathrm{hm}^{3}\right)$ \\
\hline cubic foot per second $\left(\mathrm{ft}^{3} / \mathrm{s}\right)$ & 0.001233 & \\
\hline & Flow rate & cubic meter per second $\left(\mathrm{m}^{3} / \mathrm{s}\right)$ \\
\hline ton per day (ton/d) & 0.02832 & metric ton per day \\
\hline
\end{tabular}

Temperature in degrees Celsius $\left({ }^{\circ} \mathrm{C}\right)$ may be converted to degrees Fahrenheit $\left({ }^{\circ} \mathrm{F}\right)$ as follows:

$$
{ }^{\circ} \mathrm{F}=\left(1.8 \times{ }^{\circ} \mathrm{C}\right)+32
$$

Temperature in degrees Fahrenheit $\left({ }^{\circ} \mathrm{F}\right)$ may be converted to degrees Celsius $\left({ }^{\circ} \mathrm{C}\right)$ as follows:

$$
{ }^{\circ} \mathrm{C}=\left({ }^{\circ} \mathrm{F}-32\right) / 1.8
$$

Vertical coordinate information is referenced to the North American Vertical Datum of 1988 (NAVD 88). Horizontal coordinate information is referenced to the North American Datum of 1983 (NAD 83).

Water year is the 12-month period from October 1 through September 30 and is designated by the year in which it ends. For example, the water year ending September 30, 2001 is called water year 2001. 


\section{Abbreviated Water-Quality Units}

$\mathrm{mg} / \mathrm{L} \quad$ milligrams per liter

$\mu \mathrm{S} / \mathrm{cm} \quad$ microsiemens per centimeter at 25 degrees Celsius

\section{Abbreviations}

$\begin{array}{ll}\text { CBNG } & \text { Coalbed natural gas } \\ \text { CC } & \text { Clear Creek near Arvada, Wyoming } \\ \text { CWC } & \text { Crazy Woman (at upper station) near Arvada, Wyoming } \\ \text { NWIS } & \text { National Water Information System } \\ \text { MSE } & \text { Mean square error } \\ \text { PR1 } & \text { Powder River at Sussex, Wyoming } \\ \text { PR2 } & \text { Powder River at Moorhead, Montana } \\ \text { R }^{2} & \text { Coefficient of determination } \\ \text { SAR } & \text { Sodium-adsorption ratio } \\ \text { USGS } & \text { U.S. Geological Survey } \\ \text { WDE0 } & \text { Wyoming Department of Environmental Quality }\end{array}$





\title{
Water-Quality Characteristics, Including Sodium- Adsorption Ratios, for Four Sites in the Powder River Drainage Basin, Wyoming and Montana, Water Years 2001-2004
}

\author{
By Melanie L. Clark and Jon P. Mason
}

\section{Abstract}

The U.S. Geological Survey, in cooperation with the Wyoming Department of Environmental Quality, monitors streams throughout the Powder River structural basin in Wyoming and parts of Montana for potential effects of coalbed natural gas development. Specific conductance and sodium-adsorption ratios may be larger in coalbed waters than in stream waters that may receive the discharge waters. Therefore, continuous water-quality instruments for specific conductance were installed and discrete water-quality samples were collected to characterize water quality during water years 2001-2004 at four sites in the Powder River drainage basin: Powder River at Sussex, Wyoming; Crazy Woman Creek near Arvada, Wyoming; Clear Creek near Arvada, Wyoming; and Powder River at Moorhead, Montana.

During water years 2001-2004, the median specific conductance of 2,270 microsiemens per centimeter at 25 degrees Celsius $(\mu \mathrm{S} / \mathrm{cm})$ in discrete samples from the Powder River at Sussex, Wyoming, was larger than the median specific conductance of $1,930 \mu \mathrm{S} / \mathrm{cm}$ in discrete samples collected downstream from the Powder River at Moorhead, Montana. The median specific conductance was smallest in discrete samples from Clear Creek $(1,180 \mu \mathrm{S} / \mathrm{cm})$, which has a dilution effect on the specific conductance for the Powder River at Moorhead, Montana. The daily mean specific conductance from continuous water-quality instruments during the irrigation season showed the same spatial pattern as specific conductance values for the discrete samples.

Dissolved sodium, sodium-adsorption ratios, and dissolved solids generally showed the same spatial pattern as specific conductance. The largest median sodium concentration (274 milligrams per liter) and the largest range of sodium-adsorption ratios (3.7 to 21) were measured in discrete samples from the Powder River at Sussex, Wyoming. Median concentrations of sodium and sodium-adsorption ratios were substantially smaller in Crazy Woman Creek and Clear Creek, which tend to decrease sodium concentrations and sodiumadsorption ratios at the Powder River at Moorhead, Montana.
Dissolved-solids concentrations in discrete samples were closely correlated with specific conductance values; Pearson's correlation coefficients were 0.98 or greater for all four sites.

Regression equations for discrete values of specific conductance and sodium-adsorption ratios were statistically significant $(p$-values $<0.001)$ at all four sites. The strongest relation $\left(\mathrm{R}^{2}=0.92\right)$ was at the Powder River at Sussex, Wyoming. Relations on Crazy Woman Creek $\left(\mathrm{R}^{2}=0.91\right)$ and Clear Creek $\left(\mathrm{R}^{2}=0.83\right)$ also were strong. The relation between specific conductance and sodium-adsorption ratios was weakest $\left(\mathrm{R}^{2}=0.65\right)$ at the Powder River at Moorhead, Montana; however, the relation was still significant. These data indicate that values of specific conductance are useful for estimating sodium-adsorption ratios.

A regression model called LOADEST was used to estimate dissolved-solids loads for the four sites. The average daily mean dissolved-solids loads varied among the sites during water year 2004. The largest average daily mean dissolved-solids load was calculated for the Powder River at Moorhead, Montana. Although the smallest concentrations of dissolved solids were in samples from Clear Creek, the smallest average daily mean dissolved-solids load was calculated for Crazy Woman Creek. The largest loads occurred during spring runoff, and the smallest loads occurred in late summer, when streamflows typically were smallest. Dissolvedsolids loads may be smaller than average during water years 2001-2004 because of smaller than average streamflow as a result of drought conditions.

\section{Introduction}

The Powder River structural basin in northeastern Wyoming and southeastern Montana contains important energy resources for the United States. Coal, conventional natural gas, oil, uranium, and most recently, coalbed natural gas (CBNG) are developed in the basin. The Powder River structural basin was estimated to contain nearly 14.3 trillion cubic feet (mean estimate) of undiscovered CBNG when it was last assessed by 
the U.S. Geological Survey (USGS) in 2001 (U.S. Geological Survey, 2002). From October 2000 to September 2004 (water years 2001-2004), the number of production wells for CBNG in Wyoming increased from 4,113 to 13,452 wells (Wyoming Oil and Gas Conservation Commission, 2005).

During the production of CBNG, water is pumped from wells, lowering hydrostatic pressure in the coalbeds and allowing the natural gas that was confined and stored within the internal surfaces and voids of the coal to flow (DeBruin and others, 2000). Water production associated with CBNG development ranged from about 1.1 to 1.8 million barrels per day during water years 2001-2004 (Wyoming Oil and Gas Conservation Commission, 2005). Currently (2006), most water produced during CBNG production in Wyoming is discharged into constructed reservoirs or into surface drainages, where it may infiltrate into the ground, become part of the streamflow, or evaporate. The quantity and quality of the produced waters varies depending on the coalbed source.

All natural waters contain dissolved solids. Dissolved solids are introduced into the water from the atmosphere, soil and rocks that the water contacts, and by human activities. Specific conductance, which is a measure of a substance's ability to conduct an electrical current at a specific temperature, can be used as an indicator of the concentration of dissolved solids in water (Hem, 1985). For some waters in the Powder River structural basin, the water that is associated with the coalbeds and discharged during the production of CBNG may have a larger specific conductance and, therefore, larger dissolvedsolids concentration than the receiving stream. During a study on the quality of coalbed waters, Rice and others (2000) found that specific conductance for coalbed waters ranged from 630 to 3,020 microsiemens per centimeter at 25 degrees Celsius $(\mu \mathrm{S} / \mathrm{cm})$. The specific conductance of waters used for irrigation has an effect on soil infiltration rates. Waters with large specific conductance values can have a positive effect on soil properties by causing flocculation and aeration of the soil; however, irrigation waters with excessive dissolved solids can have a negative effect on plant health (Hanson and others, 1993).

The concentrations of some constituents that contribute to the specific conductance of stream water also determine the suitability of water for irrigation. In particular, large concentrations of sodium can have a negative effect on soils by causing dispersion and swelling. Soil dispersion can harden the soil and decrease infiltration rates at the surface and reduce the hydraulic conductivity of the soil (Hanson and others, 1993). The ratio of sodium ions to calcium and magnesium ions can be used to predict the degree to which irrigation water tends to enter into the cation-exchange reactions in soil (U.S. Salinity Laboratory Staff, 1954). This ratio, called the sodium-adsorption ratio (SAR), is used to determine the sodium hazard for irrigation waters. As the SAR increases, the sodium hazard increases; therefore, the suitability of water for irrigation decreases. The effect of irrigation water on soil infiltration rates is dependent upon the interaction between the flocculating effects of specific conductance and the dispersion effects of sodium. Soils are able to tolerate irrigation waters with large SAR values if the specific conductance values also are large (Hanson and others, 1993). Sodium has been one of the primary constituents of concern during CBNG development because concentrations of sodium and SAR values may be larger in coalbed waters than in the receiving streams. During a study on the quality of coalbed waters, Rice and others (2000) reported that values for SAR ranged from 5.7 to 29.

Concerns exist regarding the quality of some CBNG discharge waters and the effect they may have on existing stream-water quality in the Powder River structural basin. Increasing specific conductance values and SAR values in the Powder River drainage basin have been of particular concern because stream waters are an important water resource to both Wyoming and Montana. The USGS, in cooperation with the Wyoming Department of Environmental Quality (WDEQ), has monitored streams for effects from CBNG development throughout the Powder River structural basin since water year 2001, including four sites with continuous water-quality instruments for specific conductance in the Powder River drainage basin. The USGS collected continuous specific conductance data and discrete water-quality samples at two sites on the mainstem of the Powder River, one site on Crazy Woman Creek, and one site on Clear Creek (fig. 1) to characterize water quality during water years 2001-2004.

Some studies have demonstrated the usefulness of specific conductance for estimating concentrations of other ionic constituents (Christensen and others, 2000; Rasmussen and Ziegler, 2003). More specifically, a study in the Tongue River drainage basin in northeastern Wyoming and southeastern Montana has demonstrated that specific conductance can be a useful estimator of SAR (Nimick, 2004). A similar analysis of specific conductance and SAR relations in the Powder River drainage basin would be beneficial to local water managers. Concerns also have been raised about the assimilative capacity of the Powder River drainage basin to accommodate increased dissolved-solids loads as a result of CBNG. Need exists to summarize data collected from the monitoring network and develop relations that can be used to help effectively manage the CBNG development in the Powder River drainage basin.

\section{Purpose and Scope}

The purpose of this report is to characterize water-quality data collected during water years 2001-2004 at four sites in the Powder River drainage basin. Specifically, this report presents: (1) a summary of continuous streamflow and specific conductance data that were collected; (2) a summary of specific conductance, major ions, and SAR values from discrete waterquality samples; (3) regression equations for estimating SAR from specific conductance; and (4) dissolved-solids loads that were estimated using load-estimation software. The four study sites are the Powder River at Sussex, Wyoming (site PR1); Crazy Woman Creek (at upper station) near Arvada, Wyoming (site CWC); Clear Creek near Arvada, Wyoming (site CC); and the Powder River at Moorhead, Montana (site PR2). 


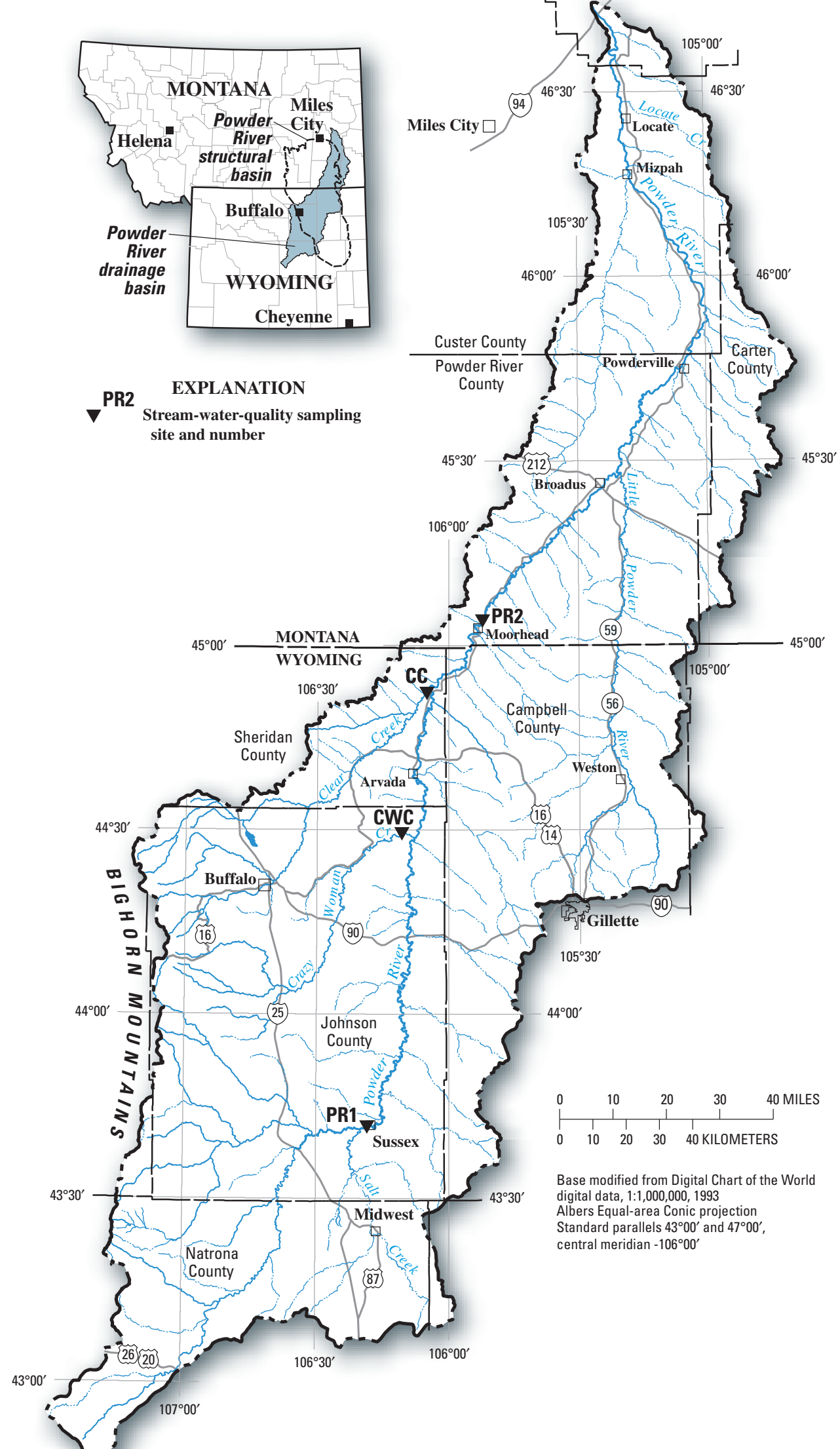

Figure 1. Location of continuous water-quality sampling sites in the Powder River drainage basin, Wyoming and Montana, water years 2001-2004. 


\section{Study Area Description}

The study area for this report includes four sites in the Powder River drainage basin from Sussex, Wyoming, to Moorhead, Montana (fig. 1, table 1). The site on the Powder River at Sussex (site PR1) is upstream from the CBNG development in the basin. The site on the Powder River at Moorhead (site PR2) is near the Montana-Wyoming Stateline and serves as a compliance point for State of Montana water-quality standards. The sites on Crazy Woman Creek (site CWC) and Clear Creek (site CC) were selected to monitor the two main tributaries that contribute to the streamflow of the Powder River in the reach from Sussex to Moorhead.

The part of the Powder River drainage basin that is within the study area extends from its headwaters in the Bighorn Mountains in Wyoming, which are part of the Middle Rocky Mountains ecoregion, to the Northwestern Great Plains ecoregion at Moorhead, Montana (Omernik, 1987). Elevation in the basin ranges from about 3,350 feet above the North American Vertical Datum of 1988 (NAVD 88) at the stream gage at Moorhead, Montana (site PR2) to more than 13,100 feet above NAVD 88 in the Bighorn Mountains. The study area in the Powder River drainage basin covers 8,088 square miles at Moorhead (table 1). The dominant land cover upstream from all the sites includes shrubland and herbaceous grassland (U.S. Geological Survey, 1992). Precipitation in the basin ranges from less than 14 inches in the plains to more than 30 inches in the Bighorn Mountains (Oregon Climate Service, 1998). A climate station at Arvada, Wyoming, reports an average annual precipitation of about 13 inches and an average temperature that ranges from less than -15 degrees Celsius in the winter to more than 21 degrees Celsius during the summer for the period from 1971 to 2000 (Western Regional Climate Center, 2005).

The geology of the basin is dominated by Eocene-age sedimentary rocks of the Wasatch Formation, which is mainly composed of conglomerate, sandstone, siltstone, and mudstones. The geology downstream from Clear Creek includes the Tongue River Member of the Fort Union Formation (Paleocene age), which is composed mainly of sandstone, siltstone, carbonaceous shale, and coal (Love and Christiansen, 1985; Bartos and Ogle, 2002).

The use designation for the Powder River in Wyoming and Crazy Woman Creek near Arvada, Wyoming, is 2ABWW and includes drinking water; recreation; wildlife; agriculture; industry; scenic view; game fish, non-game fish, and fish consumption (warmwater species); and other aquatic life (Wyoming Department of Environmental Quality, 2001a). The use designation for Clear Creek near Arvada, Wyoming, is $2 \mathrm{AB}$ and includes the same uses as a $2 \mathrm{ABWW}$ designation, except that game fish, non-game fish, and fish consumption include coldwater species (Wyoming Department of Environmental Quality, 2001a). The Powder River in Montana is classified as a B-1 water, which is to be maintained as suitable for drinking, culinary and food processing purposes, after conventional treatment; bathing, swimming and recreation; growth and propagation of salmonid fishes and associated aquatic life, waterfowl, and furbearers; and agricultural and industrial water supply (Montana Department of Environmental Quality, 2002).

\section{Acknowledgments}

The authors thank the people who assisted with data collection and preparation of the report. Thanks are extended to the USGS colleagues in the Casper, Wyoming, Field Office and the Billings, Montana, Field Office for collecting the data used in this report. Thanks also are extended to Dan Hengel, formerly with the WDEQ, and to Janet Carter, Keith Lucey, David Nimick, and Peter Wright of the USGS for providing reviews of the manuscript. Suzanne Roberts is acknowledged for the preparation of the illustrations and layout of the report.

Table 1. Selected streamflow characteristics for water-quality monitoring sites in the Powder River drainage basin, Wyoming and Montana.

\begin{tabular}{|c|c|c|c|c|c|c|}
\hline $\begin{array}{c}\text { Site } \\
\text { number } \\
\text { (fig. 1) }\end{array}$ & $\begin{array}{l}\text { U.S. Geologi- } \\
\text { cal Survey site } \\
\text { number }\end{array}$ & Site name & $\begin{array}{l}\text { Drainage area, } \\
\text { in square miles }\end{array}$ & $\begin{array}{l}\text { Period of record }{ }^{1} \\
\text { (water years) }\end{array}$ & $\begin{array}{l}\text { Mean annual } \\
\text { streamflow for } \\
\text { period of record, } \\
\text { in cubic feet per } \\
\text { second }\end{array}$ & $\begin{array}{l}\text { Mean annual } \\
\text { runoff for } \\
\text { period of record, } \\
\text { in acre-feet }\end{array}$ \\
\hline PR1 & 06313500 & $\begin{array}{l}\text { Powder River at Sussex, } \\
\text { Wyoming }\end{array}$ & 3,090 & $1938-2004$ & 201 & 145,600 \\
\hline $\mathrm{CC}$ & 06324000 & $\begin{array}{l}\text { Clear Creek near Arvada, } \\
\text { Wyoming }\end{array}$ & 1,110 & $1915-2004$ & 179 & 129,400 \\
\hline PR2 & 06324500 & $\begin{array}{l}\text { Powder River at Moorhead, } \\
\text { Montana }\end{array}$ & 8,088 & $1930-2004$ & 442 & 320,000 \\
\hline
\end{tabular}

${ }^{1}$ Based on complete water years. May include intervening water years with no record. 


\section{Methods}

The data-collection methods for continuous data and discrete water-quality samples are described in this section of the report. The data-analysis methods for estimating SAR from specific conductance and for estimating dissolved-solids loads also are described.

\section{Data Collection}

Continuous data for streamflow and specific conductance were collected by the USGS at the four study sites in the Powder River drainage basin. Streamflow gages were operated during water years 2001-2004 on Crazy Woman Creek near Arvada, Wyoming (site CWC), and the Powder River at Moorhead, Montana (site PR2). Streamflow gages were reestablished during water year 2003 on the Powder River at Sussex, Wyoming (site PR1), and Clear Creek near Arvada, Wyoming (site CC). Continuous data for streamflow are summarized in this report as daily mean values in cubic feet per second $\left(\mathrm{ft}^{3} / \mathrm{sec}\right)$. Methods for the collection and analysis of continuous streamflow are described in Rantz and others (1982). Continuous water-quality instruments for specific conductance were installed during water year 2001 on Crazy Woman Creek (site CWC) and on the Powder River at Moorhead, Montana (site PR2), and during water year 2003 on the Powder River at Sussex, Wyoming (site PR1), and on Clear Creek (site CC) after reestablishment of the streamflow gages. Continuous specific conductance was measured only during the irrigation season. Methods for the operation of continuous water-quality instruments for specific conductance are described in Wagner and others (2000). Continuous data for specific conductance are summarized in this report as daily mean values in microsiemens per centimeter at 25 degrees Celsius.

Water-quality samples were collected at all four sites during water years 2001-2004 (table 2) using methods described in the National Field Manual for the Collection of Water-Quality Data (U.S. Geological Survey, 1997 to 2006). In addition to the continuous data, discrete field measurements for streamflow and specific conductance were made during the water-quality sampling visits. For some sampling visits, streamflow was not measured but was computed from stagestreamflow ratings. For wadeable conditions, a DH-81 sampler and equal-width-integrating sampling techniques were used to collect depth- and width-integrated samples. For nonwadeable conditions, a D-95 or DH-95 sampler and equal-width-integrating sampling techniques were used to collect depth- and width-integrated samples. When the streams were too shallow for a sampler, a hand-dip method at the centroid of flow was used for collecting samples.

Samples were composited in a churn splitter and processed, preserved, and analyzed according to USGS standard methods (U.S. Geological Survey, 1997 to 2006). Samples for major ions were filtered onsite using a 0.45-micron disposable capsule filter and acidified to a $\mathrm{pH}$ less than 2 using nitric acid.
Constituents that were determined in samples filtered through the 0.45 -micron filter are referred to as "dissolved" in this report. Samples were analyzed for dissolved-major ions at the USGS National Water Quality Laboratory in Lakewood, Colorado, using an inductively coupled plasma method described in Fishman (1993). The major-ion constituents described in this report are calcium, magnesium, and sodium with concentrations reported in milligrams per liter $(\mathrm{mg} / \mathrm{L})$.

In this report, SAR values and dissolved-solids concentrations were calculated values based on laboratory results for discrete constituents. The SAR value was calculated with the analytical results of calcium, magnesium, and sodium from a discrete sample using the following equation:

$$
S A R=\frac{\left(N a^{+}\right)}{\sqrt{1 / 2\left[\left(C a^{2+}\right)+\left(M g^{2+}\right)\right]}}
$$

where $\mathrm{Na}^{+}, \mathrm{Ca}^{2+}$, and $\mathrm{Mg}^{2+}$ represent concentrations expressed in milliequivalents per liter for each constituent.

The dissolved-solids concentration is the sum of the major-ion constituents for a discrete sample, which includes major cations (dissolved calcium, magnesium, potassium, and sodium), major anions (dissolved carbonate species, chloride, fluoride, and sulfate), and nonionic silica (Hem, 1985, p. 157).

Continuous data and discrete sample results were published in Swanson and others (2002, 2003, and 2004) and Watson and others (2005). Continuous data and discrete sample results are electronically stored in the USGS's National Water Information System (NWIS) and are available to the public from NWISWeb at URL: http://waterdata.usgs.gov/nwis/.

\section{Data Analysis}

Data used for this report were analyzed using graphical and statistical techniques. Descriptive summary statistics for results from discrete water-quality samples were computed using standard methods and are presented using boxplots. For boxplots, the lower and upper edges of the box indicate the 25 th and 75 th percentiles, respectively. The median is a line within the box. Whiskers extend to -1.5 to 1.5 times the interquartile range. Points outside of this range are plotted as individual points. Parametric statistical techniques, including regression equations, were used for describing data relations. Pearson's correlation coefficient (r) is a measure of the strength and direction of relation between two variables (Helsel and Hirsch, 1992) and is shown for data where regression equations were not determined. In some cases, data were transformed to achieve a normal distribution.

One of the purposes of this report is to present regression equations for estimating SAR from specific conductance for sites on the Powder River, Crazy Woman Creek, and Clear Creek. Initial graphical inspection of the data indicated linear relations between specific conductance and SAR for the sites. 
Linear regression is a statistical technique that can be used to determine the relation between two constituents. The use of this relation can be helpful in estimating data where one constituent was measured (continuous specific conductance, in this case), but the other (continuous SAR) was not (Helsel and Hirsch, 1992). The simple linear regression equation can be expressed as:

$$
y_{i}=m x_{i}+b+e_{i} \quad i=1,2, \ldots . n,
$$

where:

$y_{i}$ is the $i$ th observation of the dependent variable; $m$ is the slope;

$x_{i}$ is the $i$ th observation of the independent, or explanatory, variable;

$b$ is the y-axis intercept;

$e_{i}$ is the random error for the $i$ th observation; and $n$ is the sample size.

The terms $m$ and $b$ are the parameters that need to be estimated from the data. The most common estimation technique is called ordinary least squares. S-PLUS statistical software (Lam, 1999) was used to generate the regression equations in this report. Plots of the residuals from the regression equation were inspected for normality. The parameters displayed in this report for the regression equations include the mean square error (MSE), which is a measure of the variance between predicted and observed values; the coefficient of determination $\left(\mathrm{R}^{2}\right)$, which is the fraction of the variance explained by the regression; and the $p$-value, which is the probability that the slope is zero, indicating that there is no correlation between the two variables. The smaller the $p$-value, the smaller the probability that the two variables are not related. For this report, a relation was determined to be statistically significant at the 95-percent confidence level. Therefore, if the calculated $p$-value was less than 0.05 , the relation is significant. Prediction intervals were determined to evaluate uncertainty of the estimated values using the regression equation (Helsel and Hirsch, 1992). For this report, the 95-percent prediction intervals were determined for the regression equation for each site. For a given specific conductance value, the 95-percent prediction interval represents the range of SAR values that are expected to occur 95 percent of the time.

Dissolved-solids loads at the four sites in the Powder River drainage basin were estimated using LOADEST, which is load-estimation software developed by the USGS (Runkel and others, 2004). LOADEST allows the user to choose from 11 different predefined regression models to solve load-estimation problems or build custom, user-defined regression models. The input parameters used in the four LOADEST models were date and time; streamflow and dissolved-solids concentration from discrete water-quality samples; and daily mean streamflow. The dissolved-solids concentrations and corresponding streamflow measurements from the same discrete water-quality samples were used to develop and calibrate a regression model for dissolved-solids load as a function of time and streamflow. The calibrated model was then used to estimate dissolved-solids loads using a time-series of streamflow values. Daily mean streamflow from USGS gages at each of the sites were used for the time-series of streamflow values in the model. The format of the regression equation predicted by LOADEST for the four sites is:

$$
\begin{gathered}
\operatorname{Ln}(y)=a_{0}+a_{1} \ln Q+a_{2} \ln Q^{2}+a_{3} \sin (2 \pi \text { dtime })+ \\
a_{4} \cos (2 \pi d t i m e)
\end{gathered}
$$

where:

$$
\begin{aligned}
& \operatorname{Ln}(y)=\text { natural } \log \text { of daily mean dissolved-solids } \\
& \text { load, in kilograms per day; } \\
& \begin{aligned}
a_{0}, a_{1}, a_{2}, a_{3}, \text { and } a_{4}=\text { model coefficients; } \\
\ln Q=(\text { natural } \log \text { of daily mean streamflow - } \\
\text { center of natural log of daily mean } \\
\text { streamflow }), \text { in cubic feet per second; and }
\end{aligned} \\
& \text { dtime }=(\text { decimal time }- \text { center of decimal time }) .
\end{aligned}
$$

The centering variables for streamflow and decimal time simplify the numerical work and have no effect on the load estimates, so that the regression coefficients are statistically independent. The dissolved-solids loads estimated from the model were converted to tons per day and are summarized using a daily mean and the 95-percent confidence interval for the daily mean. Annual dissolved-solids loads are summarized by water year in tons per year. Runoff-weighted dissolvedsolids loads, which are loads that are normalized for variations in annual runoff, also were calculated for each site in tons per acre-foot. Dissolved-solids loads for discrete sampling events were calculated using instantaneous streamflow and dissolvedsolids concentration from the discrete sample and are shown for comparison.

\section{Water-Quality Characteristics}

This section of the report summarizes water-quality characteristics from the continuous data and discrete samples. The periods of record for discrete samples used in this report are shown in table 2 and the periods of record for continuous data are shown in table 3. Data-analysis results for regression relations between specific conductance and SAR, and dissolvedsolids load estimates from LOADEST also are summarized.

\section{Streamflow and Specific Conductance from Continuous Data}

The data collection period for streamflow varied during water years 2001-2004 for the four sites in the Powder River drainage basin (table 3). The streamflow characteristics of the Powder River at Sussex, Wyoming (site PR1), and at Moorhead, Montana (site PR2), and of Crazy Woman Creek (site CWC) and Clear Creek (site CC) near Arvada, Wyoming, were a combination of those characteristics typical of 
Table 2. Period of record for discrete water-quality sample collection for sites in the Powder River drainage basin, Wyoming and Montana, water years 2001-2004.

\begin{tabular}{|c|c|c|c|c|c|}
\hline \multirow{2}{*}{$\begin{array}{l}\text { Site number } \\
\text { (fig. 1) }\end{array}$} & \multirow{2}{*}{$\begin{array}{l}\text { Period of record for discrete samples used } \\
\text { in this report }\end{array}$} & \multicolumn{4}{|c|}{ Number of discrete water-quality samples by water year } \\
\hline & & 2001 & 2002 & 2003 & 2004 \\
\hline PR1 & October 2000 -September 2004 & 4 & 12 & 24 & 24 \\
\hline $\mathrm{CWC}$ & March 2001 -September, 2004 & 7 & 12 & 24 & 24 \\
\hline $\mathrm{CC}$ & October 2000 -September, 2004 & 12 & 12 & 24 & 24 \\
\hline PR2 & May 2001 -September 2004 & 5 & 12 & 24 & 24 \\
\hline
\end{tabular}

Table 3. Period of record for continuous data collection for sites in the Powder River drainage basin, Wyoming and Montana, water years 2001-2004.

[--, no data]

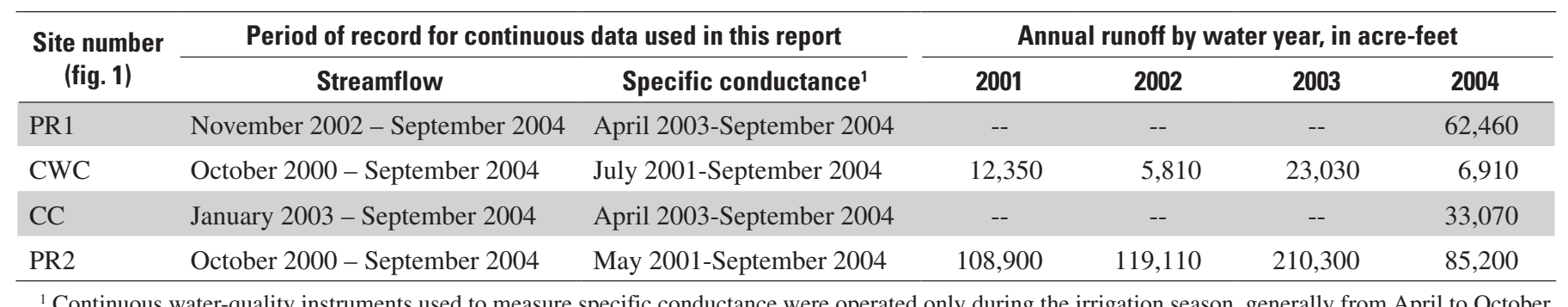

${ }^{1}$ Continuous water-quality instruments used to measure specific conductance were operated only during the irrigation season, generally from April to October.

streams that originate in the plains and streams that originate in the mountains. Hydrographs of plains streams consist of a lowland snowmelt peak during late winter through early spring and short to moderate duration rainstorm peaks that generally occur during summer months. Hydrographs of mountain streams generally are dominated by a single peak that occurs during late spring resulting from high-elevation snowmelt. The smallest streamflows at the sites typically occur during late summer. Daily mean streamflows varied substantially among sites during the study period (fig. 2).

Annual runoff during water year 2004 at all four sites (table 3) was less than mean annual runoff for their period of record (table 1) as a result of drought conditions in the basin. For example, annual runoff during water year 2004 for the Powder River at Moorhead, Montana (site PR2), was 85,200 acre-feet (table 3) compared to a mean annual runoff of 320,000 acre-feet for the period of record from 1930 to 2004 (table 1). Crazy Woman Creek near Arvada, Wyoming (site CWC), and the Powder River at Moorhead, Montana (site PR2), have annual runoff data during water years 2001-2004, and annual runoff for these two sites was substantially less than average for all 4 years.

During water year 2004, the combined annual runoff from Powder River at Sussex, Wyoming (site PR1), and Crazy Woman Creek (site CWC) and Clear Creek (site CC) near Arvada, Wyoming, was more than the annual runoff of the Powder River at Moorhead, Montana (site PR2). A study conducted on the hydrology of the Powder River alluvium between Sussex and Moorhead found that the river loses streamflow in this reach as a result of evaporation, transpiration, or seepage to ground water in the alluvium (Ringen and Daddow, 1990).

The data collection period for continuous specific conductance varied among sites during water years 2001-2004 (table 3). The use of continuous water-quality instruments greatly increases the amount of data available for specific conductance during the irrigation season compared to discrete sampling and more adequately characterizes the fluctuations of specific conductance in the streams. Despite missing records and only seasonal operation, there were 328 values of daily mean specific conductance for the Powder River at Sussex (site PR1), which had the shortest record for continuous specific conductance, and 850 values of daily mean specific conductance for the Powder River at Moorhead (site PR2), which had the longest record. These sample sizes are substantially larger than what is available for the discrete sampling events (table 2).

Daily mean specific conductance was variable and had a large range of values during the irrigation season at all four sites (fig. 2). The daily mean specific conductance for the Powder River ranged from 953 to $7,100 \mu \mathrm{S} / \mathrm{cm}$ at Sussex (site PR1), and from 492 to $5,920 \mu \mathrm{S} / \mathrm{cm}$ at Moorhead (site PR2). Although CBNG development does not occur upstream from the Powder River at Sussex (site PR1), conventional gas and oil development does occur in the Salt Creek drainage basin. Daily mean specific conductance generally 


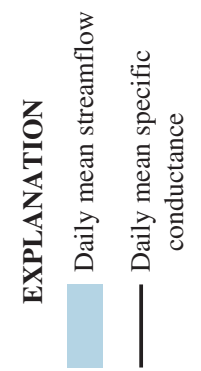

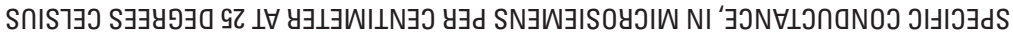
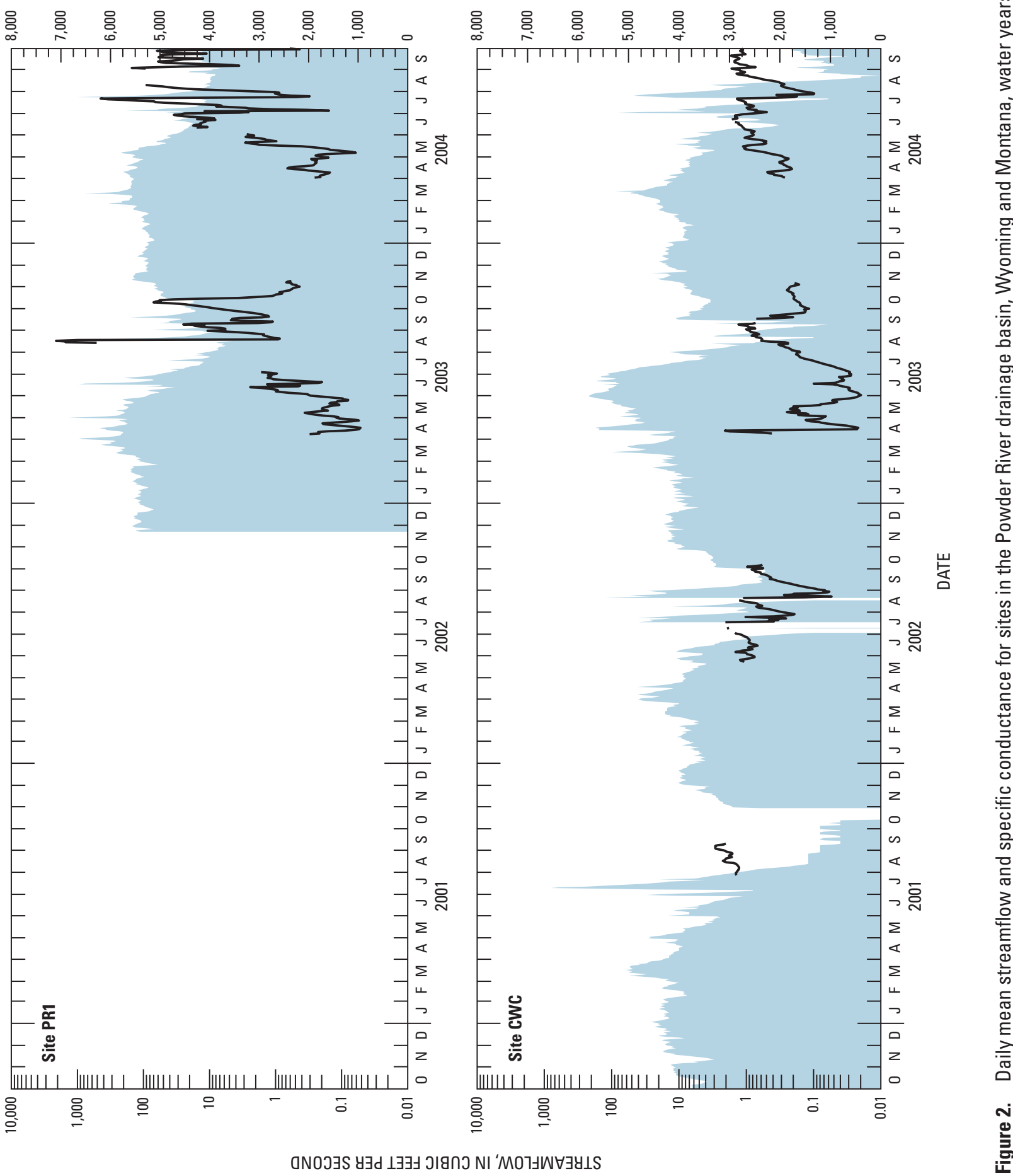

aNOJ 


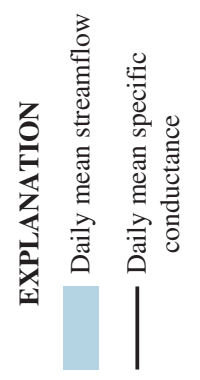

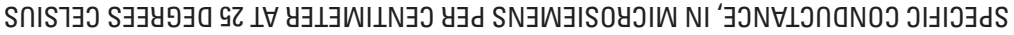
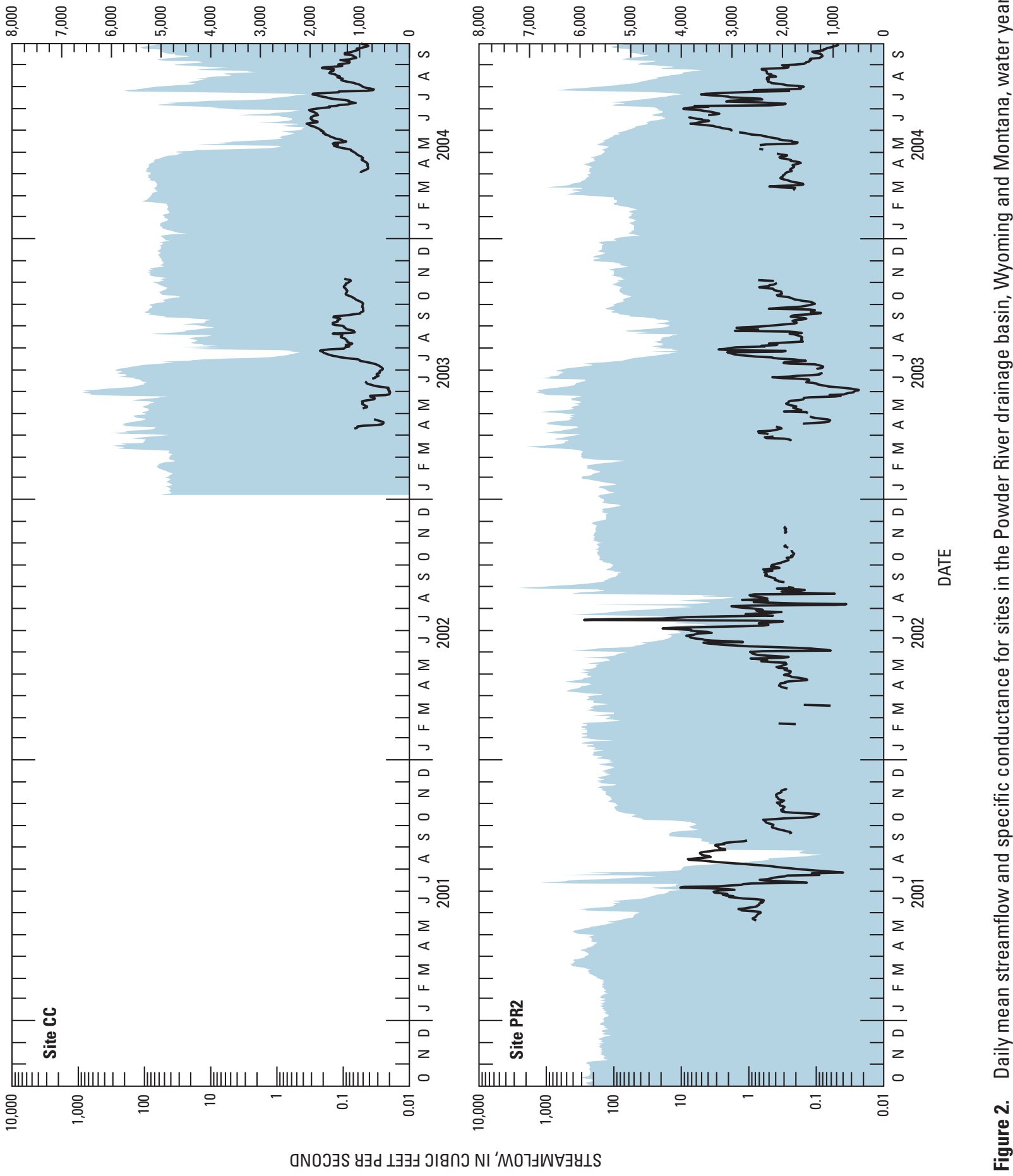
was smaller for the tributaries than for the mainstem. Daily mean values ranged from 394 to $3,280 \mu \mathrm{S} / \mathrm{cm}$ for Crazy Woman Creek (site CWC) and from 387 to $2,070 \mu \mathrm{S} / \mathrm{cm}$ for Clear Creek (site CC). Variations in specific conductance generally are associated with variations in streamflow. As streamflow increases as a result of rainfall or snowmelt, the specific conductance typically decreases as a result of dilution. For example, the smallest daily mean specific conductance of $387 \mu \mathrm{S} / \mathrm{cm}$ at Clear Creek (site CC) was associated with a daily mean streamflow of $876 \mathrm{ft}^{3} / \mathrm{sec}$ during May 2003 compared to the largest daily mean specific conductance of $2,070 \mu \mathrm{S} / \mathrm{cm}$, which was associated with a daily mean streamflow of $0.48 \mathrm{ft}^{3} / \mathrm{sec}$ during June 2004 for that site. Specific conductance values may be larger than average during water years 2001-2004 because streamflow was less than average as a result of drought conditions during this period.

The State of Montana has established water-quality standards for the Powder River for specific conductance to address concerns about irrigation water quality. From November 1 through March 1, the monthly average numeric waterquality standard is $2,500 \mu \mathrm{S} / \mathrm{cm}$ and no sample may exceed a value of 2,500 $\mu \mathrm{S} / \mathrm{cm}$; from March 2 through October 31, the monthly average numeric water-quality standard for specific conductance is $2,000 \mu \mathrm{S} / \mathrm{cm}$ and no sample may exceed a value of 2,500 $\mu \mathrm{S} / \mathrm{cm}$ (Montana Department of Environmental Quality, 2002). The daily mean specific conductance for the Powder River at Moorhead (site PR2), which is near the Wyoming-Montana Stateline, was larger than $2,500 \mu \mathrm{S} / \mathrm{cm}$ on many days, exceeding the standard established by the State of Montana for the irrigation season. However, specific conductance values in some historical samples from the Powder River at Moorhead (site PR2) that were collected prior to CBNG development also exceeded the standard (U.S. Geological Survey, 2005). The State of Wyoming has not established numeric water-quality criteria for specific conductance for the Powder River, Crazy Woman Creek, or Clear Creek (Wyoming Department of Environmental Quality, 2001b).

\section{Specific Conductance, Major lons, and Sodium- Adsorption Ratios from Discrete Samples}

Specific conductance values; concentrations of dissolved calcium, magnesium, sodium, and dissolved solids; and SAR values for discrete samples collected during water years 2001-2004 varied at the four sites (fig. 3). As with the continuous measurements, the largest median for specific conductance of 2,270 $\mu \mathrm{S} / \mathrm{cm}$ was for samples collected from the Powder River at Sussex (site PR1) and the smallest median of $1,180 \mu \mathrm{S} / \mathrm{cm}$ was for samples collected from Clear Creek (site CC). The largest range in discrete values was reported for the Powder River at Sussex (site PR1), which included values from 1,340 to $6,060 \mu \mathrm{S} / \mathrm{cm}$. The range of discrete values for the Powder River at Sussex (site PR1) was less than the range for the daily mean specific conductance reported from the continuous values, even though the discrete samples for specific conductance were collected throughout the year compared to the continuous values that were only collected during the irrigation season. The diluting effect from Clear Creek on the Powder River is reflected in the smaller median value $(1,930 \mu \mathrm{S} / \mathrm{cm})$ and smaller range of values $(483$ to 3,370 $\mu \mathrm{S} / \mathrm{cm}$ ) reported for the Powder River at Moorhead (site PR2) compared to the Powder River at Sussex (site PR1). The salinity hazard for most samples collected from the four sites is classified as high (greater than $750 \mu \mathrm{S} / \mathrm{cm}$ ) to very high (greater than 2,250 $\mu \mathrm{S} / \mathrm{cm}$ ) using the salinity hazard classification system developed by the U.S. Salinity Laboratory Staff (1954) for irrigation water based on general crop tolerances.

Dissolved calcium and magnesium showed a different spatial pattern than specific conductance, where the largest median concentrations occurred in samples from Crazy Woman Creek (site CWC). Median calcium concentrations ranged from $119 \mathrm{mg} / \mathrm{L}$ for samples collected from Clear Creek (site CC) to $164 \mathrm{mg} / \mathrm{L}$ for samples collected from Crazy Woman Creek (site CWC). Median magnesium concentrations ranged from $53 \mathrm{mg} / \mathrm{L}$ for samples collected from the Powder River at Sussex (site PR1) to $89 \mathrm{mg} / \mathrm{L}$ for samples collected from Crazy Woman Creek (site CWC).

Dissolved sodium and SAR values generally showed the same spatial pattern as specific conductance. The largest median concentration of sodium $(274 \mathrm{mg} / \mathrm{L})$ was observed in samples collected from the Powder River at Sussex (site PR1). The large sodium concentrations in samples from the Powder River at site PR1 primarily are the result of large sodium contributions from Salt Creek (Lindner-Lunsford and others, 1992). Concentrations of sodium for samples collected from Salt Creek frequently are larger than 1,000 mg/L (Swanson and others, 2002, 2003, 2004; Watson and others, 2005). Values for SAR in samples collected from the Powder River at Sussex (site PR1) ranged from 3.7 to 21. Median concentrations of sodium and SAR values were substantially smaller in samples collected from Crazy Woman Creek (site CWC) and Clear Creek (site CC), which tend to decrease sodium concentrations and SAR values in samples collected from the Powder River at Moorhead (site PR2). The smallest median concentration of sodium $(68 \mathrm{mg} / \mathrm{L})$ and smallest median SAR value (1.3) were observed in samples collected from Clear Creek (site CC). The sodium (alkali) hazard for most samples collected from Crazy Woman Creek (site CWC) and Clear Creek (site CC) is classified as low using the salinity hazard classification system developed by the U.S. Salinity Laboratory Staff (1954) for irrigation water based on general crop tolerances. The sodium (alkali) hazard ranged from low to very high for samples collected from the Powder River at Sussex (site PR1) and from low to high for samples collected from the Powder River at Moorhead (site PR2) using the salinity hazard classification system.

Sodium is more dominant in the Powder River than in Crazy Woman Creek and Clear Creek because many of the tributaries contributing to the Powder River originate in the plains to the east. The plains streams tend to have larger sodium concentrations because these drainage basins are 

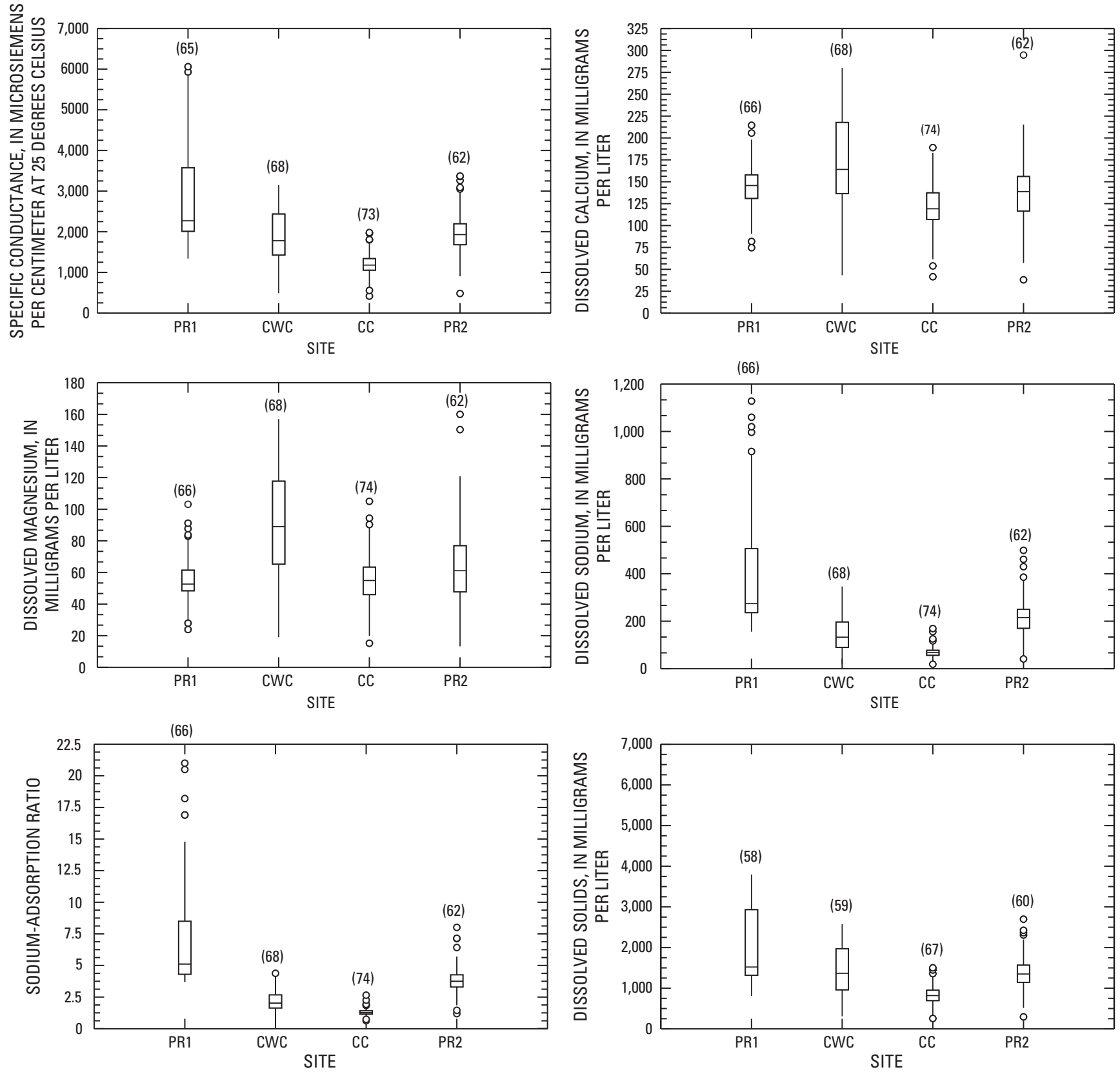

EXPLANATION

(62) Sample size

$1.5 *$ Interquartile range (IQR) or largest value

75th percentile

Median (50th percentile)

25th percentile

$-1.5 * \mathrm{IQR}$ or smallest value

- Value greater than $1.5 * \mathrm{IQR}$ or less than $-1.5 * \mathrm{IQR}$

Figure 3. Specific conductance values; concentrations of dissolved calcium, dissolved magnesium, and dissolved sodium; sodium-adsorption ratios; and dissolved-solids concentrations in water-quality samples collected from sites in the Powder River drainage basin, Wyoming and Montana, water years 2001-2004. 
underlain by Tertiary-age sedimentary rocks that contain soluble sulfate salts, and the plains have lower precipitation and higher evaporation compared to mountainous areas at the western edge of the basin. Although the sites on Crazy Woman Creek (site CWC) and Clear Creek (site CC) are in the plains, the headwaters for the creeks originate in the Bighorn Mountains. In addition to the higher annual precipitation in the mountains, the headwater areas are underlain by more resistant Paleozoic-age sedimentary rocks (Love and Christiansen, 1985).

The introduction of waters with large SAR values from CBNG discharges has the potential to affect the use of water from the Powder River for irrigation. The State of Montana has established water-quality standards for the Powder River for SAR. From November 1 through March 1, the monthly average numeric water-quality standard for SAR is 6.5 and no sample may exceed an SAR value of 9.75; from March 2 through October 31, the monthly average numeric water-quality standard for SAR is 5.0 and no sample may exceed an SAR value of 7.5 (Montana Department of Environmental Quality, 2002). One sample collected during June 2004 from the Powder River at Moorhead (site PR2) had a SAR value of

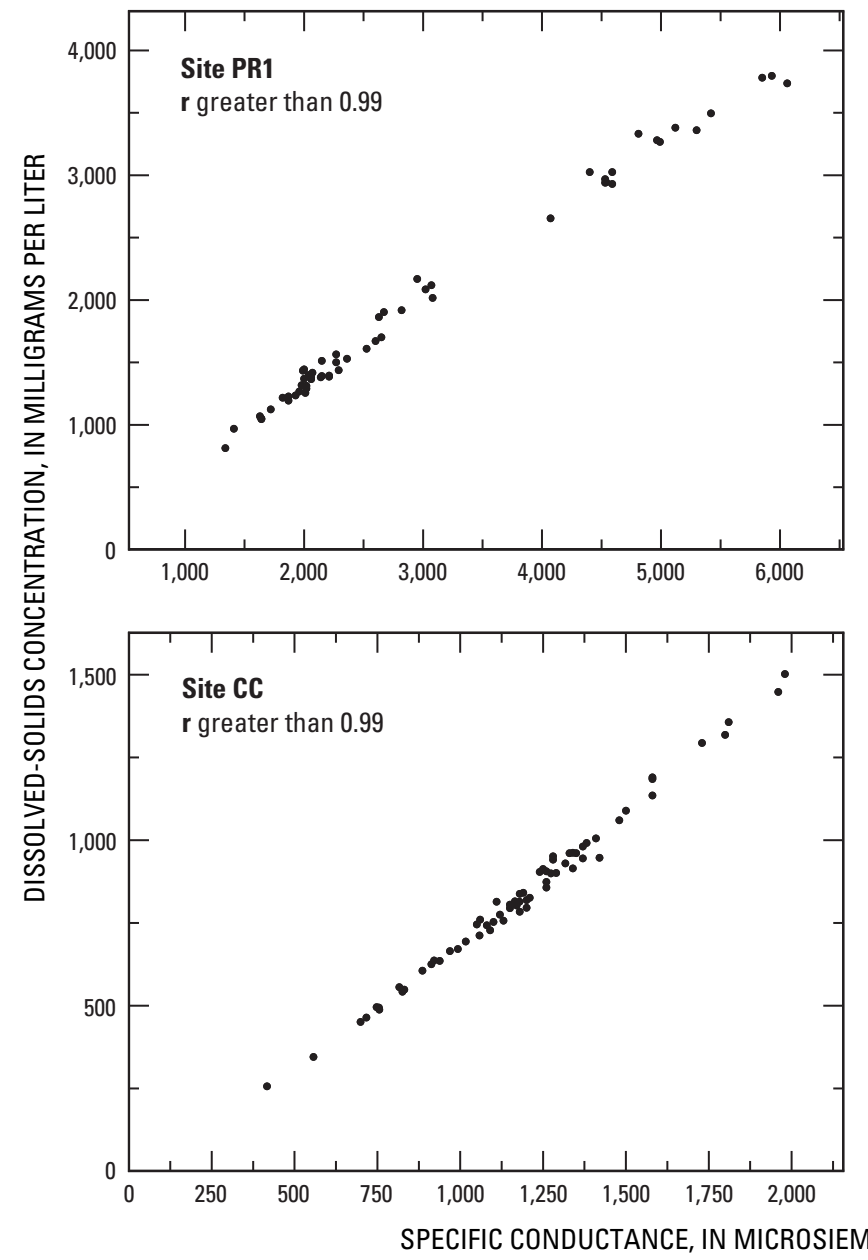

8.0, which exceeded the single-sample Montana water-quality standard of 7.5 for SAR. The State of Wyoming has not established numeric water-quality criteria for SAR for the Powder River, Crazy Woman Creek, or Clear Creek (Wyoming Department of Environmental Quality, 2001b).

Dissolved-solids concentrations show the same spatial pattern as specific conductance values. The smallest median dissolved-solids concentration was $819 \mathrm{mg} / \mathrm{L}$ for samples collected from Clear Creek (site CC) and the largest median concentration was $1,520 \mathrm{mg} / \mathrm{L}$ for samples collected from the Powder River at Sussex (site PR1). As with sodium, the eastern plains streams that are tributary to the Powder River tend to have large dissolved-solids concentrations because these drainage basins are underlain by Tertiary-age sedimentary rocks that contain soluble sulfate salts, and the plains have lower precipitation and higher evaporation compared to mountainous areas at the western edge of the basin. Dissolved-solids concentrations were strongly correlated with specific conductance. Pearson's correlation coefficients (r) were 0.98 for the Powder River at Moorhead (site PR2) and greater than 0.99 for the Powder River at Sussex (site PR1), Crazy Woman Creek (site CWC), and Clear Creek (site CC) (fig. 4).
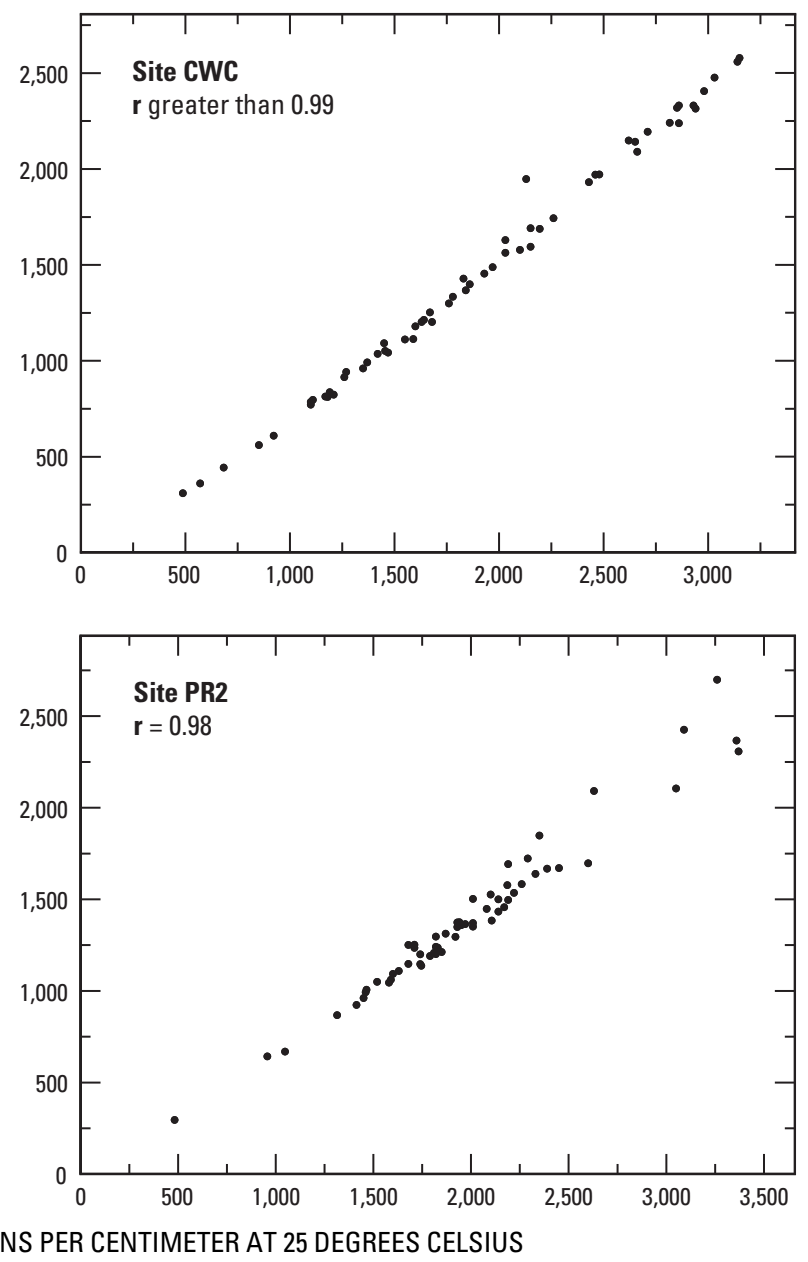

Figure 4. Dissolved-solids concentrations in relation to specific conductance in water-quality samples collected from sites in the Powder River drainage basin, Wyoming and Montana, water years 2001-2004. 
Specific conductance and SAR values for discrete samples collected from the four study sites in the Powder River drainage basin were plotted on a diagram that was modified from Hanson and others (1993) and that describes potential for reduction in the rate of infiltration from irrigation waters for a range of specific conductance and SAR values (fig. 5). Most of the samples plot in the area of the diagram where no reduction in the rate of infiltration is expected. One sample each from Crazy Woman Creek (site CWC), Clear Creek (site CC), and the Powder River at Moorhead (site PR2) plotted in the area where a slight to moderate reduction in the rate of infiltration may occur. These samples had the smallest specific conductance values for samples collected at those sites. The suitability of water for irrigation also is dependent on the salt toler- ance of the crops and soil texture, which this diagram does not show.

\section{Regression Equations for Estimating Sodium- Adsorption Ratios}

Specific conductance data can help irrigators assess the suitability of water for irrigation; however, as previously described, the suitability of water for irrigation is a function of both specific conductance and SAR. The relations between specific conductance (independent variable) and SAR values (dependent variable) for the discrete samples collected from the four sites in the Powder River drainage basin during water

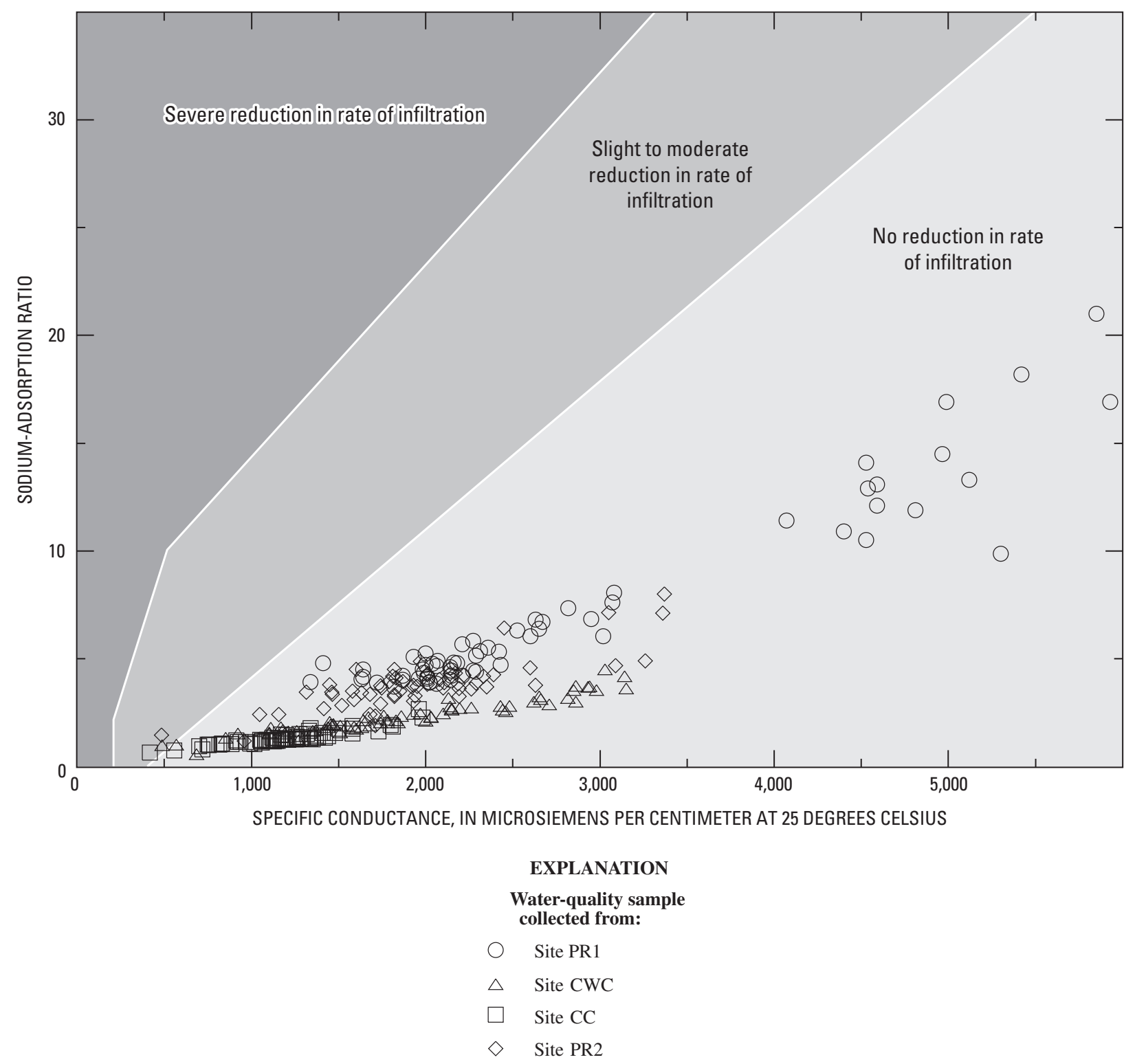

Figure 5. Diagram showing specific conductance and sodium-adsorption ratio and potential for reduction in rate of infiltration for water-quality samples collected from sites in the Powder River drainage basin, Wyoming and Montana, water years 2001-2004 (modified from Hanson and others, 1993). 
years 2001-2004 were graphically inspected (fig. 6). Data were inspected to determine if relations of specific conductance and SAR varied by season. Although diversions for irrigation exist, relations did not vary by season for the Powder River at Sussex (site PR1) and at Moorhead (site PR2). Relations for Crazy Woman Creek (site CWC) and Clear Creek (site CC) did vary slightly by season; however, the slope of the regression did not change and the difference in the intercept value was small. The complete discrete-sample data sets were used for consistency among sites. The specific conductance and SAR relations were determined to be statistically significant ( $p$-values $<0.001$ ) at each site, and the linear regression equations are presented for the four sites in table 4 .

The relation between specific conductance and SAR was stronger $\left(R^{2}=0.92\right)$ at the Powder River at Sussex (site PR1) compared to the Powder River at Moorhead (site PR2, $\mathrm{R}^{2}=0.65$ ). In other words, about 92 percent of the variance in SAR values in samples collected from the Powder River at Sussex (site PR1) can be explained by the regression with specific conductance compared to about 65 percent of the variance in SAR values that can be explained by the regression at the Powder River at Moorhead (site PR2). The substantially larger drainage area of the Powder River at Moorhead has more diverse areas contributing to streamflow and specific conductance compared to the Powder River at Sussex (site PR1). Contributing areas include eastern tributaries originating from the plains and western tributaries originating from the mountains. In addition, several drainages in the reach between site PR1 and site PR2 may contribute CBNG discharge waters to the Powder River. The variable contributing areas probably produce the additional scatter in data for the Powder River at site PR2. Ground-water and surface-water interactions also occur in this reach of the Powder River (Ringen and Daddow, 1990). The coefficients of determination for Crazy Woman Creek (site CWC, $\mathrm{R}^{2}=0.91$ ) and Clear Creek (site $\mathrm{CC}, \mathrm{R}^{2}=0.83$ ) were in between the values for the Powder River at Sussex (site PR1) and at Moorhead (site PR2). The uncertainty associated with estimated values is larger for the Powder River at Sussex (site PR1) and Moorhead (site PR2), compared to Crazy Woman Creek (site CWC) and Clear Creek (site CC), as indicated by larger MSE values and wider prediction intervals for the regression equations for these sites.

The linear regression equation was used to estimate continuous SAR values from the continuous specific conductance values. The estimated SAR values from the regression equation were compared to the SAR values calculated from the discrete samples (fig. 7). The discrete sample results for SAR generally covered the range of estimated SAR values for Crazy Woman Creek (site CWC) and Clear Creek (site CC). For the Powder River at Sussex (site PR1), smaller SAR values were estimated from specific conductance than were calculated for discrete samples probably owing to precipitation-event waters with small specific conductance values that were not sampled. In contrast, some estimated SAR values were larger than calculated values for discrete samples at site PR2. The estimated SAR values may more adequately characterize the fluctuations of SAR values that occur in the streams because the continuous specific conductance values show more fluctuations.

Although values of SAR calculated from calcium, magnesium, and sodium concentrations from discrete samples provide a more accurate measure of SAR, laboratory results may not be available until several months after sample collection. The regression relations indicate that SAR values estimated from specific conductance values are a good surrogate for laboratory analyses. Specific conductance can be measured by continuous water-quality instruments, and values are available in real time using NWISWeb (http://waterdata.usgs. gov/nwis/). Using real-time specific conductance to estimate SAR values increases the amount of information available to irrigators and water managers for decision making.

\section{Estimates for Dissolved-Solids Loads}

The USGS load estimation model, LOADEST, was used to estimate daily mean and annual dissolved-solids loads at the four sites in the Powder River drainage basin. Daily mean dissolved-solids load estimates and annual dissolved-solids load estimates for Crazy Woman Creek (site CWC) and the Powder River at Moorhead (site PR2) were calculated for water years 2001-2004. Daily mean dissolved-solids load estimates for the Powder River at Sussex (site PR1) and Clear Creek (site CC) could only be calculated when daily mean streamflow data were collected during water years 2003 and 2004. Dissolvedsolids loads were calculated for discrete sampling events during water years 2001-2004 at all four sites.

The LOADEST regression models for the four sites had coefficients of determination $\left(\mathrm{R}^{2}\right)$ ranging from 0.95 to 0.98 (table 5) indicating that 95 to 98 percent of the variance in dissolved-solids loads at the sites can be explained by the regressions with streamflow. The estimated daily mean dissolved-solids loads during water years 2001-2004 ranged from $<0.1$ to 330 tons per day (tons/d) for Crazy Woman Creek (site CWC), and from 0.3 to 3,290 tons/d for the Powder River at Moorhead (site PR2) (fig. 8). The estimated daily mean dissolved-solids loads during water years 2003-2004 ranged from 62 to 4,000 tons/d for the Powder River at Sussex (site PR1) and from 1.0 to 440 tons/d for Clear Creek (site CC). For all sites, the largest dissolved-solids loads generally occurred in the early spring in response to snowmelt runoff. The smallest dissolved-solids loads generally occurred in the late summer when streamflows typically were smallest. Dissolved-solids loads calculated for discrete sampling events plotted near the estimated dissolved-solids loads and generally covered the range of dissolved-solids loads estimated by LOADEST at all four sites. Because of drought conditions and below average streamflows during water years 2001-2004, the dissolved-solids loads also may be below average.

In order to compare the sites during a common time period, the average daily mean dissolved-solids loads for water year 2004 are shown in table 5. The average daily mean dissolved-solids loads varied substantially among the four 
Table 4. Regression equations for estimates of sodium-adsorption ratios for sites in the Powder River drainage basin, Wyoming and Montana, water years 2001-2004.

[SAR, sodium-adsorption ratio; $S C$, specific conductance in microsiemens per centimeter at 25 degrees Celsius; MSE, mean square error; $\mathrm{R}^{2}$, coefficient of determination; <, less than]

\begin{tabular}{lllll}
\hline \multicolumn{1}{c}{ Site number (fig. 1) } & \multicolumn{1}{c}{ Equation } & MSE & $\mathbf{R}^{2}$ & $\boldsymbol{p}$-value \\
\hline PR1 & $S A R=0.0033(S C)-2.2$ & 1.29 & 0.92 & $<0.001$ \\
CWC & $S A R=0.0011(S C)+0.088$ & 0.242 & .91 & $<.001$ \\
CC & $S A R=0.0010(S C)+0.17$ & .130 & .83 & $<.001$ \\
PR2 & $S A R=0.0018(S C)+0.38$ & .711 & .65 & $<.001$ \\
\hline
\end{tabular}
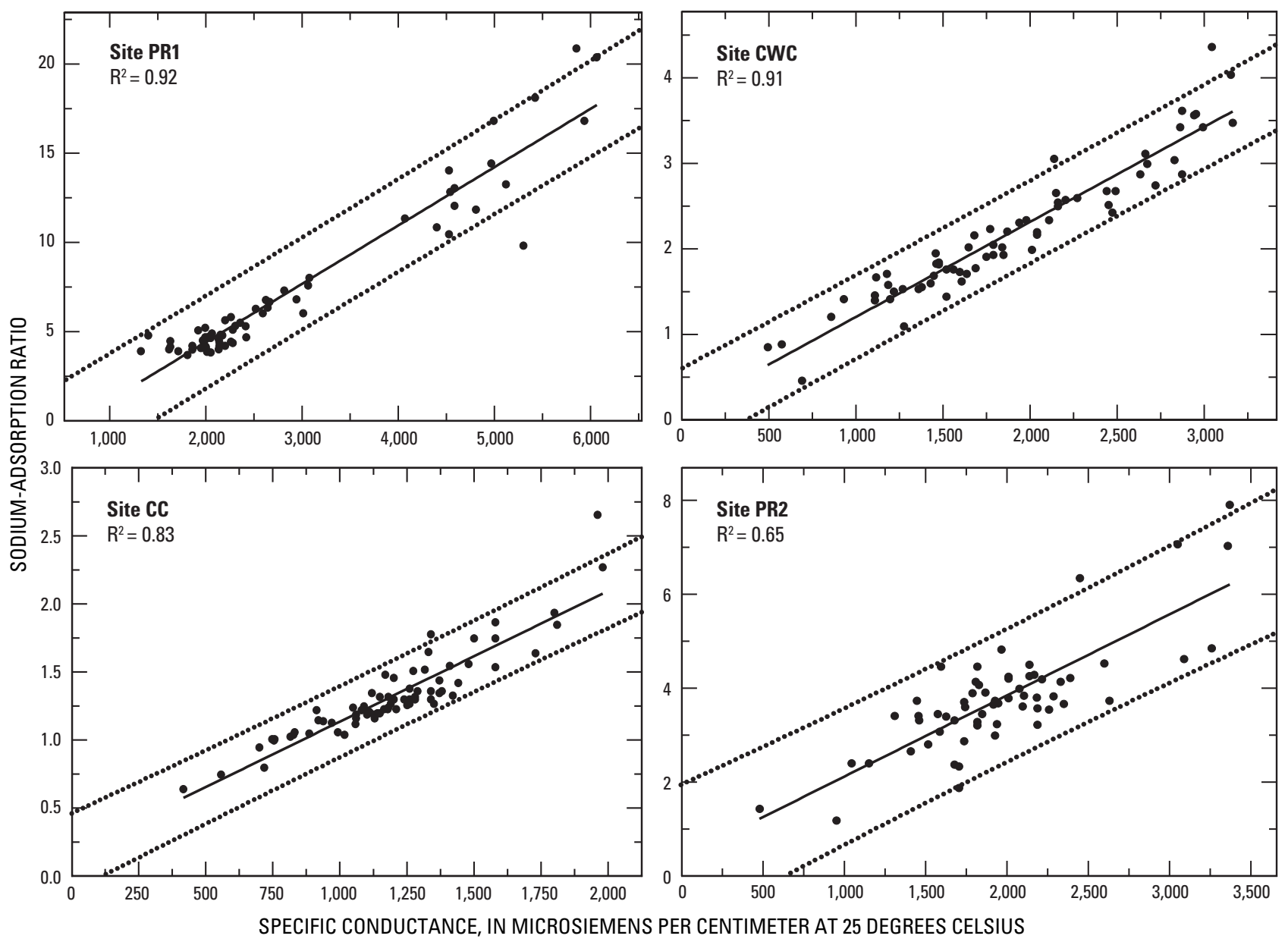

\section{EXPLANATION}

Linear regression line

95-percent prediction interval

Figure 6. Sodium-adsorption ratios in relation to specific conductance in water-quality samples collected from sites in the Powder River drainage basin, Wyoming and Montana, water years 2001-2004. 


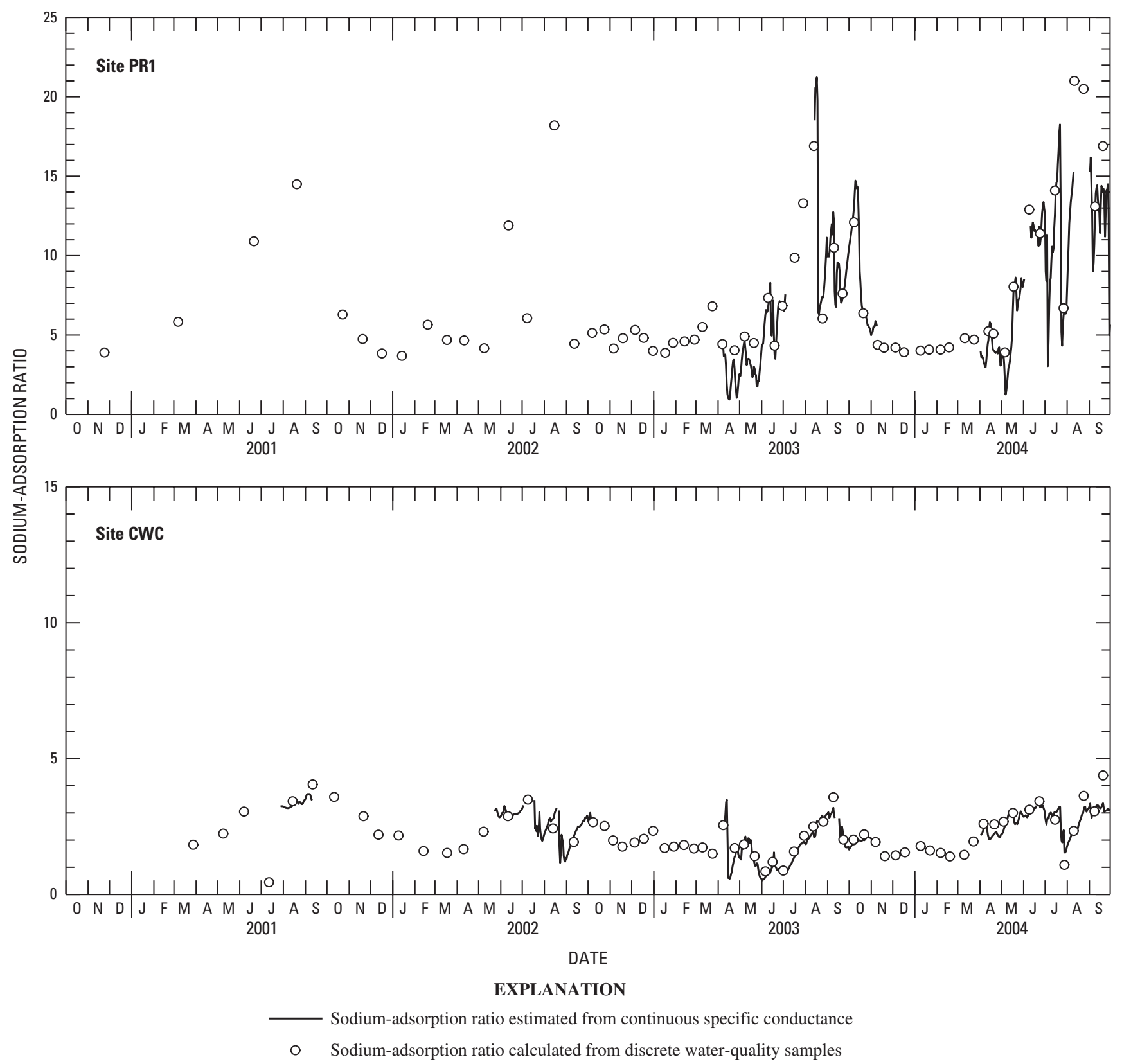

Figure 7. Estimated and calculated sodium-adsorption ratios for sites in the Powder River drainage basin, Wyoming and Montana, water years 2001-2004. 


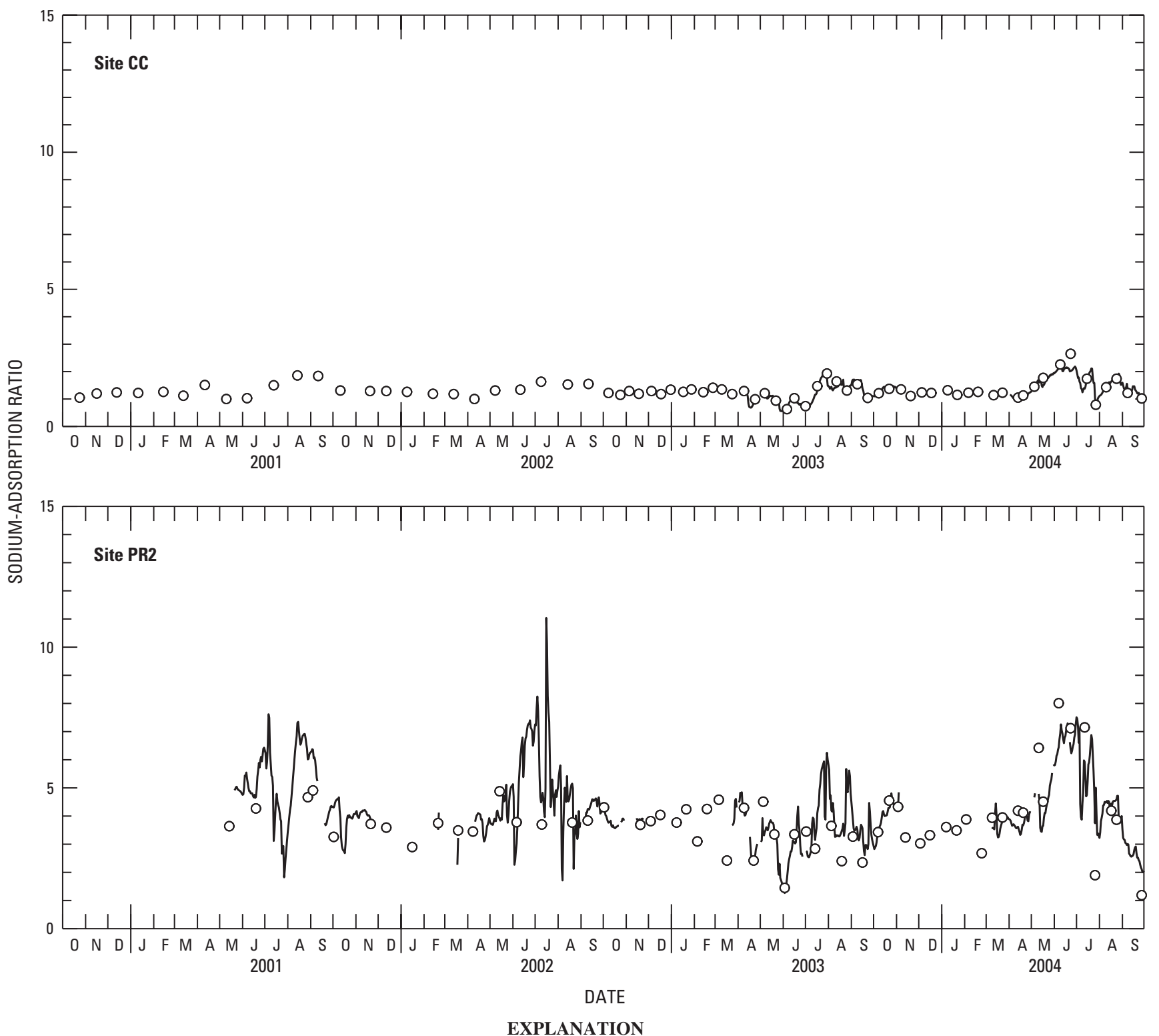

\section{EXPLANATION}

Sodium-adsorption ratio estimated from continuous specific conductance

○ Sodium-adsorption ratio calculated from discrete water-quality samples

Figure 7. Estimated and calculated sodium-adsorption ratios for sites in the Powder River drainage basin, Wyoming and Montana, water years 2001-2004._- Continued 
sites during water year 2004. Although the smallest concentrations of dissolved solids were in samples from Clear Creek (site CC), the smallest average daily mean dissolved-solids load (29.2 tons/d) was estimated for Crazy Woman Creek (site CWC), which has the smallest mean annual runoff (table 1). The largest average daily mean dissolved-solids load (407 tons/d) was estimated for the Powder River at Moorhead (site PR2). This is expected given that site PR2 has the largest mean annual runoff and receives dissolved-solids loads from the other three upstream sites.

Annual dissolved-solids loads and runoff-weighted dissolved-solids loads for water years 2001-2004 were estimated for Crazy Woman Creek (site CWC) and the Powder River at Moorhead (site PR2, table 6). Annual load estimates for the Powder River at Sussex (site PR1) and Clear Creek (site CC) could only be estimated for water year 2004 because this was the only year with a complete streamflow record. During water year 2004, site PR2 had the largest dissolved-solids load estimate of 149,000 tons per year. The annual load at site PR2 during water year 2004 was less than the combined annual loads for the Powder River at Sussex (site PR1), Crazy Woman Creek (site CWC), and Clear Creek (site CC) probably as a result of streamflow losses between Sussex and Moorhead.

When loads were weighted for variations in annual runoff, the Powder River at Sussex (site PR1) had the largest dissolved-solids load estimate of 2.05 tons per acre-foot. Site PR1 also had the largest dissolved-solids concentrations. The smallest runoff-weighted dissolved-solids load was estimated for Clear Creek (site CC), which had the smallest dissolved-solids concentrations. The Powder River at Moorhead (site PR2) had a larger runoff-weighted dissolved-solids load than Clear Creek, and, to a lesser extent, Crazy Woman Creek, indicating these tributaries have a diluting effect on the Powder River at site PR2.

Table 5. Summary statistics of LOADEST regression models used to estimate daily mean dissolved-solids loads for sites in the Powder River drainage basin, Wyoming and Montana, water years 2001-2004.

$\left[\mathrm{R}^{2}\right.$, coefficient of determination]

\begin{tabular}{lccccc}
\hline $\begin{array}{c}\text { Site number } \\
\text { (fig. 1) }\end{array}$ & $\begin{array}{c}\text { Number of days of } \\
\text { estimated record }\end{array}$ & $\begin{array}{c}\text { Period of record used } \\
\text { in this report } \\
\text { (water years) }\end{array}$ & $\mathbf{R}^{2}$ & $\begin{array}{c}\text { 95-percent confidence } \\
\text { Average daily mean dis- } \\
\text { solved-solids load for water } \\
\text { year 2004, in tons per day }\end{array}$ & $\begin{array}{c}\text { interval for the average daily } \\
\text { mean dissolved-solids load } \\
\text { for water year 2004, in tons } \\
\text { per day }\end{array}$ \\
\hline PR1 & 679 & $22003-04$ & 0.95 & 349 & $330-369$ \\
\hline CWC & 1,432 & $2001-04$ & .98 & 29.2 & $27.1-31.5$ \\
\hline CC & 633 & $22003-04$ & .98 & 94.2 & $89.5-99.0$ \\
\hline PR2 & 1,461 & $2001-04$ & .96 & 407 & $375-440$ \\
\hline
\end{tabular}

${ }^{1}$ Site had 29 days with zero streamflow that could not be used in the model.

${ }^{2}$ Only partial streamflow record available during water year 2003

Table 6. Estimated dissolved-solids annual loads and runoff-weighted loads for sites in the Powder River drainage basin, Wyoming and Montana, water years 2001-2004.

$[--$, not determined]

\begin{tabular}{|c|c|c|c|c|c|c|c|c|}
\hline \multirow{3}{*}{$\begin{array}{c}\text { Site } \\
\text { number } \\
\text { (fig. 1) }\end{array}$} & \multicolumn{8}{|c|}{ Water Year } \\
\hline & \multicolumn{2}{|c|}{2001} & \multicolumn{2}{|c|}{2002} & \multicolumn{2}{|c|}{2003} & \multicolumn{2}{|c|}{2004} \\
\hline & $\begin{array}{l}\text { Load, } \\
\text { tons per year }\end{array}$ & $\begin{array}{c}\text { Load, } \\
\text { tons per } \\
\text { acre-foot }\end{array}$ & $\begin{array}{l}\text { Load, } \\
\text { tons per year }\end{array}$ & $\begin{array}{l}\text { Load, } \\
\text { tons per } \\
\text { acre-foot }\end{array}$ & $\begin{array}{l}\text { Load, } \\
\text { tons per year }\end{array}$ & $\begin{array}{c}\text { Load, } \\
\text { tons per } \\
\text { acre-foot }\end{array}$ & $\begin{array}{c}\text { Load, } \\
\text { tons per year }\end{array}$ & $\begin{array}{c}\text { Load, } \\
\text { tons per } \\
\text { acre-foot }\end{array}$ \\
\hline PR1 & -- & -- & -- & -- & -- & -- & 128,000 & 2.05 \\
\hline PR2 & 178,000 & 1.64 & 187,000 & 1.57 & 282,000 & 1.34 & 149,000 & 1.75 \\
\hline
\end{tabular}



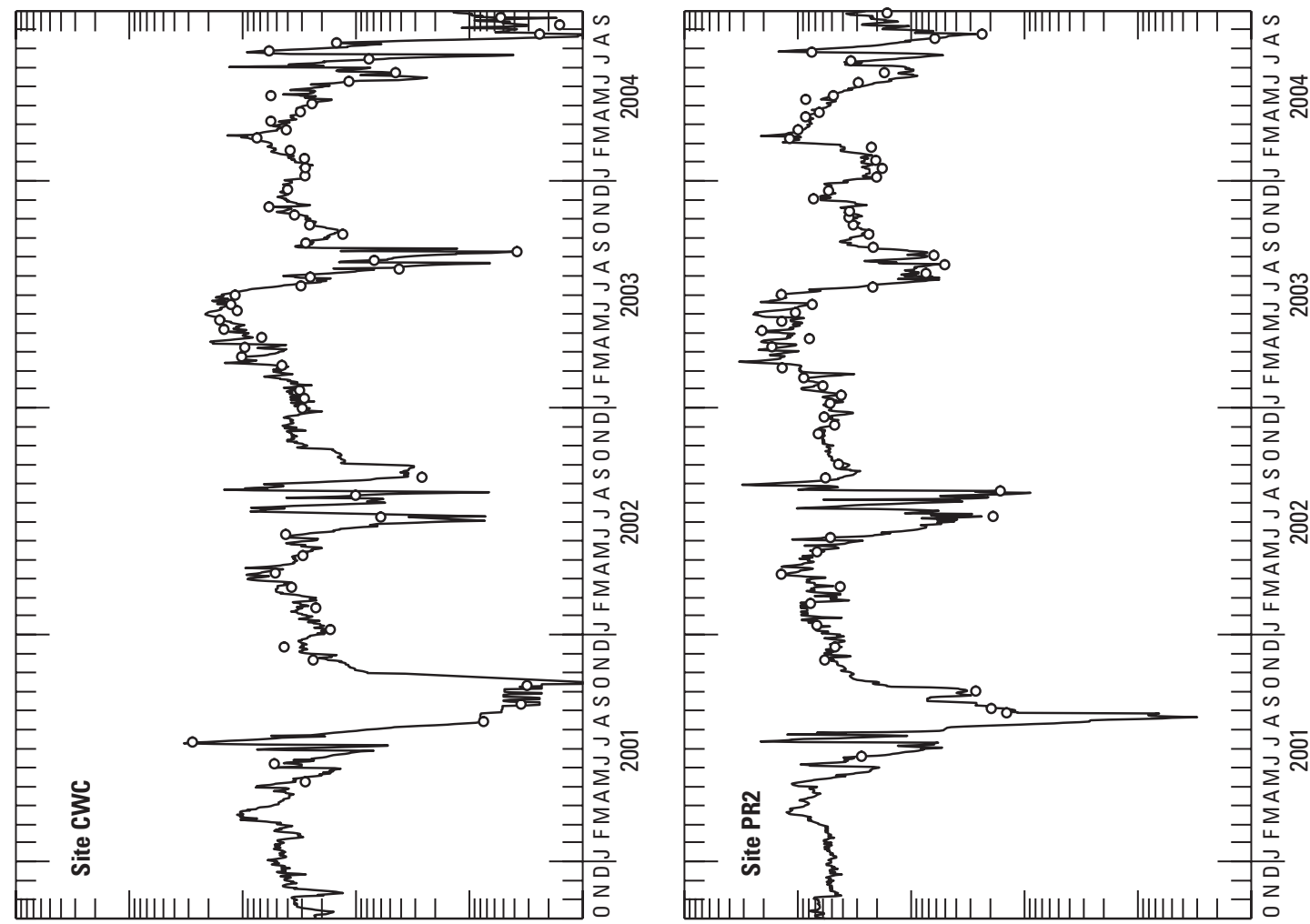

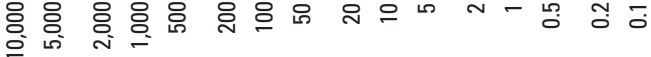
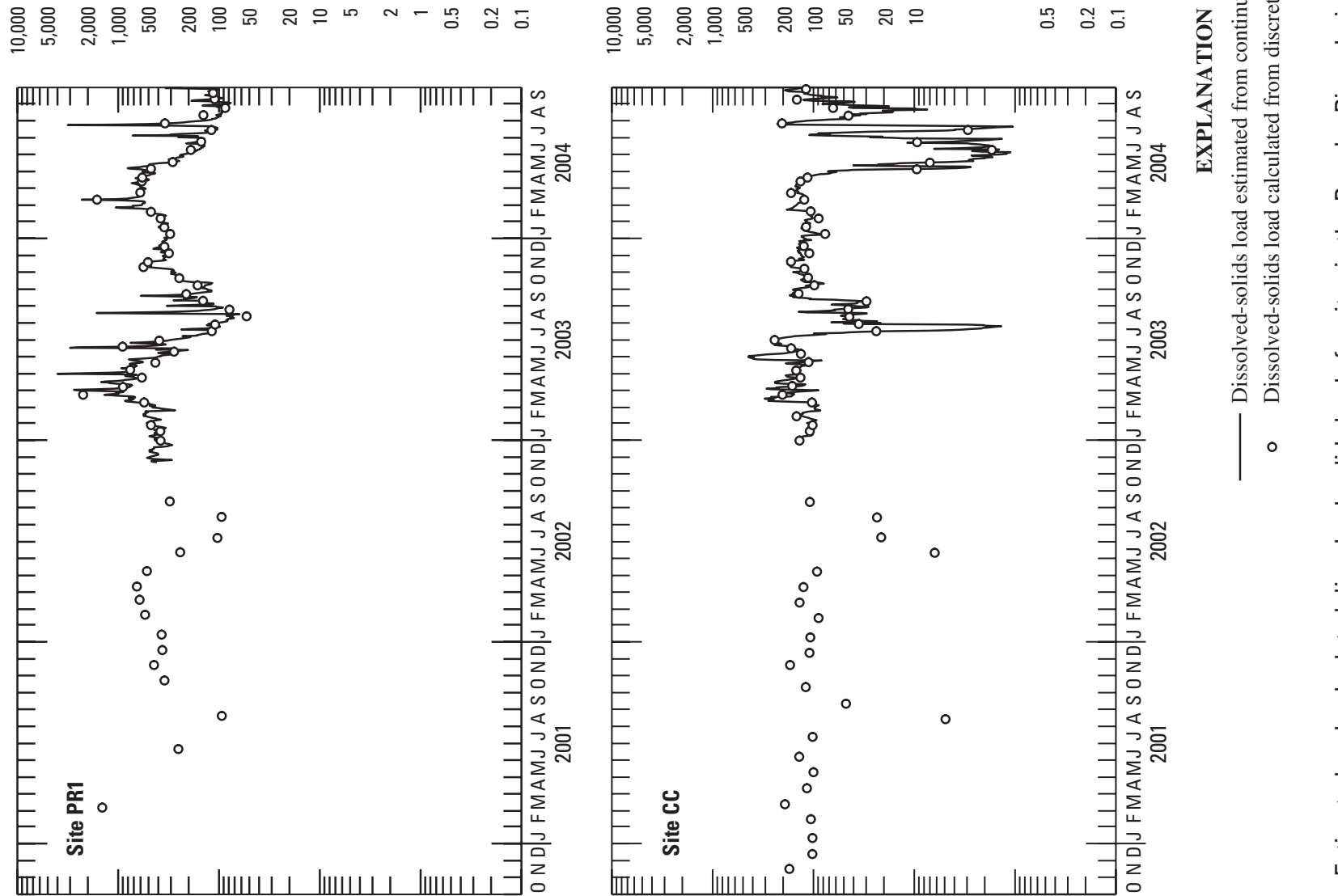

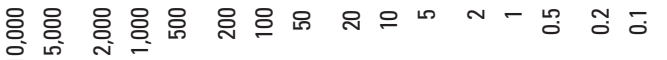

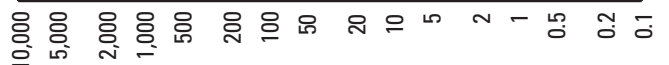




\section{Summary}

The U.S. Geological Survey, in cooperation with the Wyoming Department of Environmental Quality, monitors streams throughout the Powder River structural basin in Wyoming and parts of Montana in response to concerns over coalbed natural gas development. Because coalbed waters may have specific conductance values and sodium-adsorption ratio (SAR) values that are larger than the stream waters that may receive discharge waters, continuous water-quality instruments for specific conductance were installed and discrete waterquality samples were collected to characterize water quality during water years 2001-2004 at four sites in the Powder River drainage basin: the Powder River at Sussex, Wyoming; Crazy Woman Creek near Arvada, Wyoming; Clear Creek near Arvada, Wyoming; and the Powder River at Moorhead, Montana.

During water years 2001-2004, the median specific conductance of 2,270 microsiemens per centimeter at 25 degrees Celsius $(\mu \mathrm{S} / \mathrm{cm})$ in discrete samples from the Powder River at Sussex, Wyoming, was larger than the median specific conductance of $1,930 \mu \mathrm{S} / \mathrm{cm}$ in discrete samples downstream on the Powder River at Moorhead, Montana. The median specific conductance was smallest in discrete samples from Clear Creek $(1,180 \mu \mathrm{S} / \mathrm{cm})$, which has a dilution effect on the specific conductance for the Powder River at Moorhead, Montana. The daily mean values for specific conductance from continuous water-quality instruments during the irrigation season showed the same spatial pattern as discrete values from samples. Specific conductance values may have been elevated in some samples collected at all four sites owing to drought conditions during water years 2001-2004.

Dissolved sodium, SAR values, and dissolved solids generally showed the same spatial pattern as specific conductance. The largest median sodium concentration (274 milligrams per liter) and the largest range of SAR values (3.7 to 21) were measured in samples from the Powder River at Sussex, Wyoming. Although the Powder River at Sussex, Wyoming is upstream from coalbed natural gas development, the site receives inputs from Salt Creek. Conventional gas and oil development occur in the Salt Creek drainage basin. Median concentrations of sodium and SAR values were substantially smaller in Crazy Woman Creek and Clear Creek, which tend to decrease sodium concentrations and SAR values at the Powder River at Moorhead, Montana. Dissolved-solids concentrations in discrete samples were closely correlated with specific conductance values; Pearson's correlation coefficients were 0.98 or greater for all four sites.

Regression equations for specific conductance and SAR were statistically significant ( $p$-values $<0.001$ ) at all four sites. The strongest relation $\left(\mathrm{R}^{2}=0.92\right)$ was at the Powder River at Sussex, Wyoming. Relations on Crazy Woman Creek $\left(\mathrm{R}^{2}=0.91\right)$ and Clear Creek $\left(\mathrm{R}^{2}=0.83\right)$ also were strong. The relation between specific conductance and SAR was weakest $\left(R^{2}=0.65\right)$ at the Powder River at Moorhead, Montana.
These data indicate that values for specific conductance from continuous water-quality instruments are useful for estimating sodium-adsorption ratios in real time.

A regression model called LOADEST was used to estimate dissolved-solids loads for the four sites. The average daily mean dissolved-solids loads varied among the sites during water year 2004. The largest average daily mean dissolved-solids load was calculated for the Powder River at Moorhead, Montana. Although the smallest concentrations of dissolved solids were in samples from Clear Creek, the smallest average daily mean dissolved-solids load was calculated for Crazy Woman Creek. The largest loads occurred during spring runoff, and the smallest loads occurred in late summer, when streamflows typically were smallest. Dissolved-solids loads may be smaller than average during water years 2001-2004 as a result of drought conditions.

\section{References}

Bartos, T.T., and Ogle, K.M., 2002, Water quality and environmental isotopic analyses of ground-water samples collected from the Wasatch and Fort Union Formations in areas of coalbed methane development-Implications to recharge and ground-water flow, eastern Powder River Basin, Wyoming: U.S. Geological Survey Water-Resources Investigations Report 02-4045, 88 p.

Christensen, V.G., Jian, Xiaodong, and Ziegler, A.C., 2000, Regression analysis and real-time water-quality monitoring to estimate constituent concentrations, loads, and yields in the Little Arkansas River, south-central Kansas, 1995-99: U.S. Geological Survey Water-Resources Investigations Report 00-4126, 36 p.

DeBruin, R.H., Lyman, R.M., Jones, R.W., and Cook, L.W., 2000, Coalbed methane in Wyoming: Wyoming State Geological Survey Information Pamphlet 7, 15 p.

Fishman, M.J., ed., 1993, Methods of analysis by the U.S. Geological Survey National Water Quality LaboratoryDetermination of inorganic and organic constituents in water and fluvial sediments: U.S. Geological Survey OpenFile Report 93-125, 217 p.

Hanson, B.R., Grattan, S.R., and Fulton, A., 1993, Agricultural salinity and drainage: Davis, California, University of California Irrigation Program, Water Management Handbook Series, Publication 93-01, 141 p.

Helsel, D.R., and Hirsch, R.M., 1992, Statistical methods in water resources: New York, Elsevier Science Publishers, $522 \mathrm{p}$.

Hem, J.D., 1985, Study and interpretation of the chemical characteristics of natural water (3d ed.): U.S. Geological Survey Water-Supply Paper 2254, 263 p. 
Lam, Longhow, 1999, An introduction to S-PLUS for Windows: Amsterdam, The Netherlands, CANdiensten, $164 \mathrm{p}$.

Lindner-Lunsford, J.B., Parrett, Charles, Wilson, J.F. Jr., and Eddy-Miller, C.A., 1992, Chemical quality of surface water and mathematical simulation of the surface-water system, Powder River drainage basin, northeastern Wyoming and southeastern Montana: U.S. Geological Survey WaterResources Investigations Report 91-4199, 85 p.

Love, J.D., and Christiansen, A.C., 1985, Geologic map of Wyoming: U.S. Geological Survey, scale 1:500,000, 3 sheets.

Montana Department of Environmental Quality, 2002, Administrative rules of Montana-Title 17, chapter 30, water quality, sub-chapter 6 , surface-water quality standards and procedures, September 30, 2002, 52 p.: accessed Aug. 10, 2005, at http://www.deq.state.mt.us/dir/Legal/Chapters/ CH30-06.pdf.

Nimick, D.A., 2004, Monitoring surface-water quality in the Tongue River watershed: U.S. Geological Survey Fact Sheet 2004-3011, 2 p.

Omernik, J.M., 1987, Ecoregions of the conterminous United States: Annals of the Association of American Geographers, v. 77, no. 1, p. 118-125, scale 1:7,500,000.

Oregon Climate Service, 1998, Western U.S. average monthly precipitation, 1961-90: Corvallis, Oregon State University, Oregon Climate Service, digital data, accessed Aug. 10, 2005, at http://www.ocs.orst.edu/pub/maps/Precipitation/ Total/States/WY/wy.gif.

Rantz, S.E., and others, 1982, Measurement and computation of streamflow-volume 1, measurement of stage and discharge: U.S. Geological Survey Water-Supply Paper 2175, $284 \mathrm{p}$.

Rasmussen, P.P., and Ziegler, A.C., 2003, Comparison and continuous estimates of fecal coliform and Escherichia coli bacteria in selected Kansas streams, May 1999 through April 2002: U.S. Geological Survey Water-Resources Investigations Report 03-4056, 87 p.

Rice, C.A., Ellis, M.S., and Bullock, J.H., Jr., 2000, Water coproduced with coalbed methane in the Powder River Basin, Wyoming - preliminary compositional data: U.S. Geological Survey Open-File Report 00-372, 20 p.

Ringen, B.H., and Daddow, P.B., 1990, Hydrology of the Powder River alluvium between Sussex, Wyoming and Moorhead, Montana: U.S. Geological Survey Water-Resources Investigations Report 89-4002, 48 p.
Runkel, R.L., Crawford, C.G., and Cohn, T.A., 2004, Load Estimator (LOADEST) - A FORTRAN program for estimating constituent loads in streams and rivers: U.S. Geological Survey Techniques and Methods, book 4, chap. A5, $69 \mathrm{p}$.

Swanson, R.B., Miller, K.A., Woodruff, R.E., Laidlaw, G.A., Watson, K.R., and Clark, M.L., 2003, Water resources data, Wyoming, water year 2002, volume 1, surface water: U.S. Geological Survey Water-Data Report WY-02-1, 526 p.

Swanson, R.B., Miller, K.A., Woodruff, R.E., Laidlaw, G.A., Watson, K.R., and Clark, M.L., 2004, Water resources data, Wyoming, water year 2003, volume 1, surface water: U.S. Geological Survey Water-Data Report WY-03-1, 531 p.

Swanson, R.B., Woodruff, R.E., Laidlaw, G.A., Watson, K.R., and Clark, M.L., 2002, Water resources data, Wyoming, water year 2001, volume 1, surface water: U.S. Geological Survey Water-Data Report WY-01-1, 518 p.

U.S. Geological Survey, 1992, National Land Cover Dataset (NLCD): Sioux Falls, South Dakota, U.S. Geological Survey digital data, accessed Aug. 10, 2005, at http://landcover. usgs.gov/natllandcover.asp.

U.S. Geological Survey, 1997 to 2006, National field manual for the collection of water-quality data: U.S. Geological Survey Techniques of Water-Resources Investigations, book 9, chaps. A1-A9, 2 v. [variously paged], (also available at http://pubs.water.usgs.gov/twri9A). Chapters originally were published from 1997-1999; updates and revisions are ongoing and are summarized at $h t t p: / /$ water.usgs. gov/owq/FieldManual/mastererrata.html.

U.S. Geological Survey, 2002, Assessment of undiscovered oil and gas resources of the Powder River Basin Province of Wyoming and Montana, 2002: U.S. Geological Survey Fact Sheet FS-146-02, 2 p.

U.S. Geological Survey, 2005, National Water Information System Web digital data: accessed Aug. 10, 2005 at http:// nwis.waterdata.usgs.gov/usa/nwis/qw.

U.S. Salinity Laboratory Staff, 1954, Diagnosis and improvement of saline and alkali soils: U.S. Department of Agriculture Handbook 60, 160 p.

Wagner, R.J., Mattraw, H.C., Ritz, G.F., and Smith, B.A., 2000, Guidelines and standard procedures for continuous water-quality monitors - site selection, field operation, calibration, record computation, and reporting: U.S. Geological Survey Water-Resources Investigations Report 00-4252, $53 \mathrm{p}$. 
Watson, K.R., Woodruff, R.E., Laidlaw, G.A., Clark, M.L., and Miller, K.A., 2005, Water resources data, Wyoming, water year 2004, volume 1, surface water: U.S. Geological Survey Water-Data Report WY-04-1, 578 p.

Western Regional Climate Center, 2005, Wyoming Climate Summaries: Reno, Desert Research Institute, Western Regional Climate Center, digital data, accessed Aug. 10, 2005, at http://www.wrcc.dri.edu/summary/climsmwy.html.

Wyoming Department of Environmental Quality, 2001a, Wyoming surface water classification list: Wyoming Department of Environmental Quality, Water Quality Division, Surface Water Standards, June 21, 2001 [variously paged], accessed Mar. 28, 2006, at http://deq.state.wy.us/wqd/watershed/ surfacestandards/Downloads/Standards/2-3648-doc.pdf.

Wyoming Department of Environmental Quality, 2001b, Water quality rules and regulations, Chapter 1 , Wyoming surface water quality standards: Wyoming Department of Environmental Quality, Water Quality Division, June 21, 2001 [variously paged], accessed Mar. 28, 2006, at http://deq. state.wy.us/wqd/WQDrules/Chapter_01.pdf.

Wyoming Oil and Gas Conservation Commission, 2005, digital data, accessed Aug, 10, 2005, at http://wogcc.state. wy.us/coalbedchart.cfm.

For more information concerning the research in this report, contact:

Director

Wyoming Water Science Center

U.S. Geological Survey

2617 E. Lincolnway, Suite B

Cheyenne, Wyoming 82001-5662

(307) 778-2931

http://wy.water.usgs.gov/ 

